\title{
New narrow-range endemic land snails from the sky islands of northern South Africa (Gastropoda: Streptaxidae and Urocyclidae)
}

\author{
David G. HERBERT \\ KwaZulu-Natal Museum, P. Bag 9070, Pietermaritzburg, 3200, South Africa and School of Life \\ Sciences, University of KwaZulu-Natal, P. Bag X01, Scottsville, 3209, South Africa. \\ E-mail: phasianella@gmail.com
} urn:Isid:zoobank.org:author:0C09EE45-6198-482E-857A-EF690C2A016F

\begin{abstract}
One new genus and five new species of land snails are described from high altitude, insular, Afrotemperate forest habitats in northern South Africa. The distribution of these species is discussed in relation to other narrowly endemic land snails occurring in this and neighbouring regions. The new genus is Ptilototheca gen. nov.; the five new species are: Gulella davisae sp. nov., G. hadroglossa sp. nov., Ptilototheca soutpansbergensis gen. et sp. nov., Sheldonia monsmaripi sp. nov. and S. wolkbergensis sp. nov.
\end{abstract}

Keywords. New species, insular habitats, Afrotemperate forest, narrow-range endemism.

Herbert D.G. 2016. New narrow-range endemic land snails from the sky islands of northern South Africa (Gastropoda: Streptaxidae and Urocyclidae). European Journal of Taxonomy 236: 1-29. http://dx.doi.org/10.5852/ ejt.2016.236

\section{Introduction}

A discontinuous chain of high elevation massifs spans the eastern regions of Africa extending, with many intermediary stepping stones, from the Ethiopian highlands in the north through the well-known peaks of Mt Kenya and Kilimanjaro, the Eastern Arc Mountains of Tanzania and the highlands on the Zimbabwe-Mozambique border, finally ending in southern Africa's Great Escarpment. The biota of these massifs is profoundly influenced by the climatic phenomena created by their elevated position relative to the surrounding landscape matrix. Commonly this results in orographic precipitation and lower temperatures, generating conditions favourable for the growth of temperate rainforest (cloud forest). The environments thus created typically contrast sharply with those of the adjacent lower altitude regions and the massif habitats are effectively high altitude, insular ecosystems, which are increasingly termed 'sky islands'.

The composition of the biota of these islands reflects not only their mesic, temperate habitats, but also the impact of climate fluctuations that have resulted in repeated expansion and contraction in their extent and thus their connectivity. One therefore encounters both widespread elements (genera and species) characteristic of cooler, wetter environments that point to confluence and interchange, as well as insular endemics that emphasise fragmentation and isolation. Invertebrates of limited vagility often fall into 
the latter category and are prone to narrow-range endemism. In this paper I document five recently discovered examples of such endemism in the land snail fauna of sky islands of northern South Africa.

The material studied was collected in the Soutpansberg of northern Limpopo and the northern Drakensberg escarpment of southern Limpopo and northern Mpumalanga. Van Wyk \& Smith (2001) have recognised both of these areas as centres of plant endemism, highlighting the unique flora associated with these pockets of Afrotemperate habitat. Similarly, Govender (2007) identified them as foci of site and local endemism for terrestrial molluscs. The Soutpansberg rises from the surrounding landscape to a high point of $1748 \mathrm{~m}$ and its south facing slopes receive orographic rain with mean annual precipitation reaching $2000 \mathrm{~mm}$ at the highest altitudes. The summit regions are frequently shrouded in cloud. Geologically, the major rock types are sandstone and quartzite, and the soils are sandy, acidic and low in nutrients. The northern Drakensberg region, known as the Wolkberg Centre of Plant Endemism (Van Wyk \& Smith 2001), is bisected by the hot, arid valley of the Olifants River that delimits two subcentres. North of this river, the Serala Subcentre includes the Wolkberg itself, reaching a height of $2126 \mathrm{~m}$; south of the river, the Blyde Subcentre runs along the edge of the Mpumalanga escarpment, with Mariepskop reaching a height of $1994 \mathrm{~m}$. Mean annual precipitation exceeds $1000 \mathrm{~mm}$ in both subcentres, attaining $2000 \mathrm{~mm}$ at high points on the escarpment edge, where the rocks are quartzitic, and the soils sandy, acidic and heavily leached.

\section{Material and methods}

The material studied has been accumulated over many years, beginning with the field expeditions of Dr A.C. van Bruggen to the Soutpansberg in 1965 and Mariepskop in 1966, and including inter alia the invertebrate surveys of Johanna Horn [née Swaye] in 2001-2006 (Horn 2004). More detailed study of urocyclid samples from this region, including specimens identified only as Sheldonia sp., led to the discovery of three undescribed species. These were then selected as target species for further survey work in November 2014, in order to obtain more precise microhabitat data and to acquire additional material for anatomical study. It also enabled the animals to be examined and photographed alive. Whilst sampling for urocyclid material, two further undescribed species referable to Gulella s.l. were identified among general land snail samples collected for inventory purposes. All live-collected samples were drowned overnight in sealed containers and subsequently preserved in $75 \%$ ethanol. For selected specimens, tissue samples from the hind end of the foot were excised prior to drowning and preserved in $99 \%$ ethanol for on-going molecular studies.

All dissections were performed under a Wild M4 dissecting microscope with drawing tube. Shells of urocyclid species were photographed using a Nikon D70 camera and living specimens with a Nikon CoolPix 8800. Shells of Gulella species were photographed using a Zeiss Stemi 2000-C dissecting microscope with AxioCam ERc5s digital camera and stacked images were combined using Helicon Focus Pro (Helicon Soft Ltd) to provide extended depth of field. Radulae were extracted by maceration of the buccal mass in dilute $\mathrm{NaOH}$, rinsed in distilled water. For light microscopy radulae were stained in Shirlastain A (SDLAtlas). For SEM examination radulae were dehydrated in ethanol, mounted and air-dried on stubs, coated with gold-palladium, and examined at low accelerating voltage (5 kv) in a Zeiss EVO 10LS scanning electron microscope. Immature shells were excluded from the data used to calculate H:D ratios.

Abbreviations for morphological
$\begin{array}{ll}\mathrm{ad} & =\text { atrial diverticulum } \\ \mathrm{ag} & =\text { albumen gland } \\ \mathrm{apc} & =\text { apical penial caecum } \\ \mathrm{bp} & =\text { basal penis pilaster } \\ \mathrm{ec} & =\text { epiphallic caecum }\end{array}$




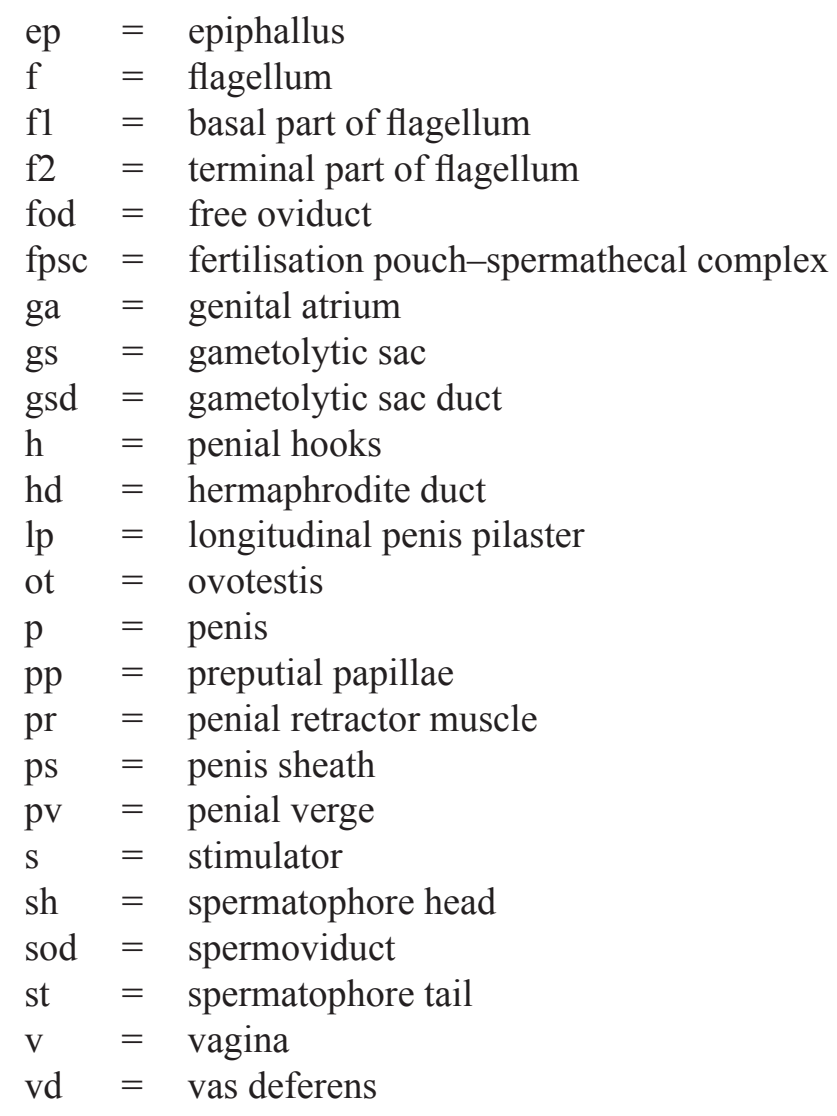

\section{Institutional abbreviations}

ELM $=$ East London Museum, East London, South Africa

NHMUK $=$ Natural History Museum, London, UK

NMSA $=$ KwaZulu-Natal Museum, Pietermaritzburg, South Africa

RMNH $=$ Naturalis Biodiversity Center, Leiden, The Netherlands

\section{Results}

Class Gastropoda Cuvier, 1795

Family Streptaxidae Gray, 1860

Genus Gulella Pfeiffer, 1856 (sensu lato)

Gulella Pfeiffer, 1856: 173. Type species: Pupa menkeana Pfeiffer, 1853 [subsequent designation by Martens, 1860: 298].

Gulella davisae sp. nov.

urn:1sid:zoobank.org:act:DDCAA18B-CC50-4EC1-B63B-28ABAF6904C2

Figs $1-2$

\section{Etymology}

Named for Linda Davis, manager of the Mollusca collection at the KwaZulu-Natal Museum and a key member of the institution's malacological field work team. 


\section{Material examined}

\section{Holotype}

SOUTH AFRICA: Mpumalanga, Mariepskop Forest Reserve, $24.56128^{\circ} \mathrm{S}, 30.86367^{\circ} \mathrm{E}, 1700 \mathrm{~m}$, scrubby vegetation between road and forest, in leaf-litter, D. Herbert, L. Davis \& M. Cole, stn 14-26, 4 Dec. 2014, height $6.1 \mathrm{~mm}$, diameter $2.9 \mathrm{~mm}$ (NMSA P0418/T4086, dry shell).

Paratypes (listed from north to south)

SOUTH AFRICA: Mpumalanga, same data as holotype (NMSA P0245/T4088, 5 dry specimens; NHMUK 20160037, one dry specimen; RMNH.5004141, one dry specimen); Mariepskop Forest Reserve, $24.56374^{\circ} \mathrm{S}, 30.86293^{\circ} \mathrm{E}, 1640 \mathrm{~m}$, northern mist-belt forest, in leaf-litter, D. Herbert, L. Davis \& M. Cole, stn 14-22, 3 Dec. 2014 (NMSA P0269/T4090, three dry specimens, one in ethanol); Mariepskop Forest Reserve, $24.56692^{\circ} \mathrm{S}, 30.86482^{\circ} \mathrm{E}, 1520 \mathrm{~m}$, indigenous Afromontane forest, in leaf-litter on forest floor, J.L. Horn, 1 Mar. 2005 (NMSA W3501/T4087, three dry specimens); Mariepskop Forest Reserve, $24.5679^{\circ} \mathrm{S}, 30.8599^{\circ} \mathrm{E}, 1550 \mathrm{~m}$, northern mist-belt forest, in leaf-litter, D. Herbert, L. Davis \& M. Cole, stn 14-26a, 4 Dec. 2014 (NMSA P0240/T4092, one dry specimen); Mariepskop Forest Reserve, Bushpig Trail, $24.56795^{\circ} \mathrm{S}, 30.86138^{\circ} \mathrm{E}, 1520 \mathrm{~m}$, northern mist-belt forest, in leaf-litter, D. Herbert,
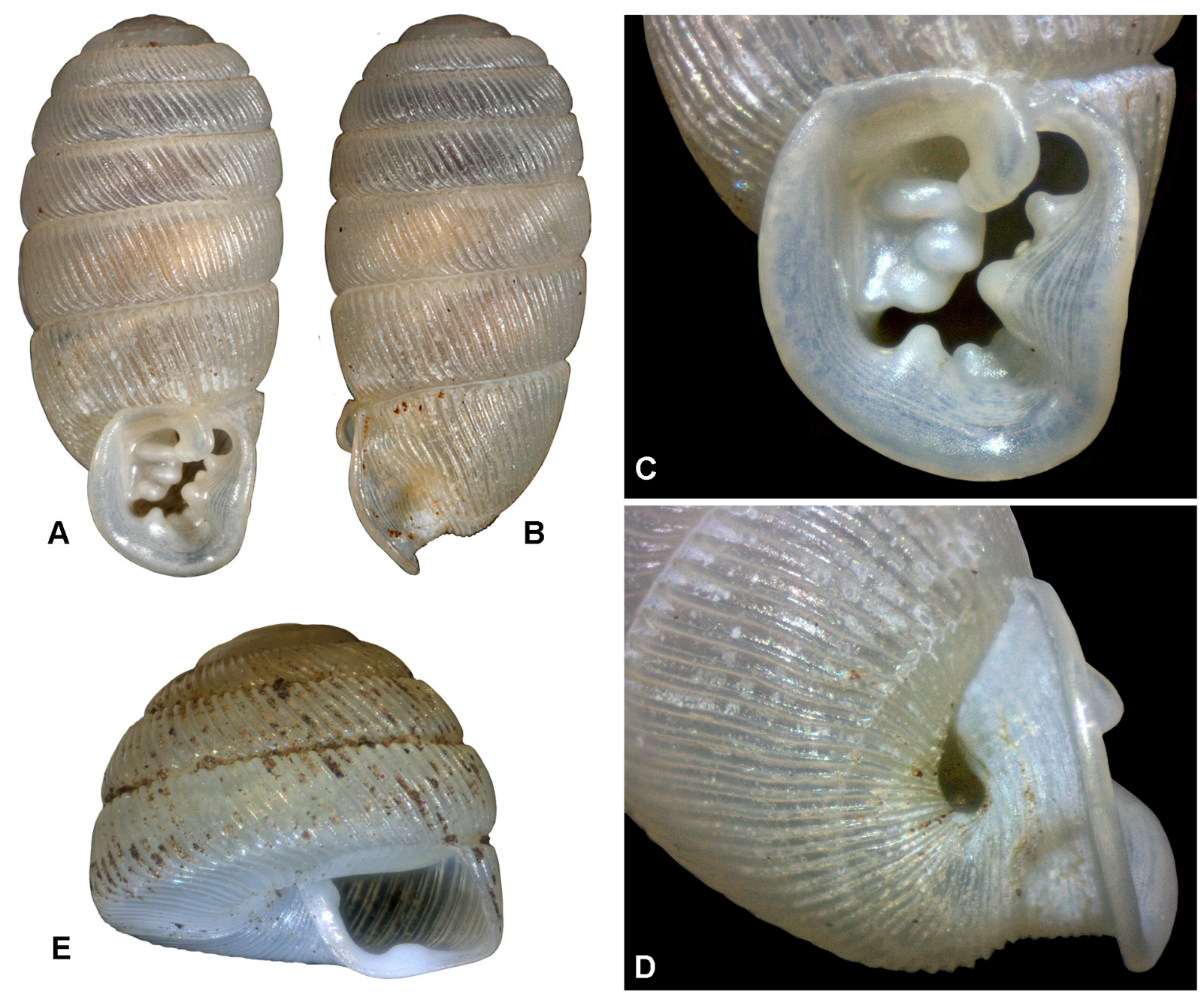

Fig. 1. Gulella davisae sp. nov. A-D. Holotype, height $6.1 \mathrm{~mm}$, diameter $2.9 \mathrm{~mm}$ (NMSA P0418/ T4086). E. Juvenile specimen showing apertural dentition, diameter $2.7 \mathrm{~mm}$ (paratype, NMSA P0235/ T4091). 
L. Davis \& M. Cole, stn 14-22a, 3 Dec. 2014 (NMSA P0262/T4089, one dry specimen); Mariepskop Forest Reserve, Picnic Trail, $24.56847^{\circ} \mathrm{S}, 30.85920^{\circ} \mathrm{E}, 1545 \mathrm{~m}$, northern mist-belt forest, in leaflitter, D. Herbert, L. Davis \& M. Cole, stn 14-27, 4 Dec. 2014 (NMSA P0235/T4091, one dry juvenile specimen); Mariepskop Forest Reserve, east facing slope, $24.57108^{\circ} \mathrm{S}, 30.86014^{\circ} \mathrm{E}, 1519 \mathrm{~m}$, leg. M. Cole, 10 Dec. 2013 (ELM D17729/T035, one dry specimen); Mariepskop Forest Reserve, in forest beside road at 1520-1700 m, leg. M. Cole, 3-4 Dec. 2014 (ELM D18022/T036, three dry specimens; ELM W3882/T037, two specimens in ethanol).

\section{Type locality}

SOUTH AFRICA: Mpumalanga, Mariepskop Forest Reserve, $24.56128^{\circ} \mathrm{S}, 30.86367^{\circ} \mathrm{E}, 1700 \mathrm{~m}$.

\section{Identification}

A moderately sized species of Gulella with a strongly ribbed, cylindrical shell and five-fold apertural dentition including, inter alia, a tricuspid mid-labral complex and a tricuspid columella lamella; also distinctive is the almost complete peristome, interrupted only behind the parietal lamella.

\section{Description}

SHELl (Fig. 1). Medium-sized, cylindrical; adult height 5.6-6.3 mm, diameter 2.8-3.0 mm; H:D 1.952.21, with up to 8.0 whorls. Protoconch diameter $1.1-1.3 \mathrm{~mm}$, comprising 1.5-2.0 whorls beyond nucleus, sculptured with fine, close-set axial wrinkles, with an indistinct spiral element appearing in the last halfwhorl; junction with teleoconch distinct. Teleoconch comprising 5.5-6.0 whorls; whorls weakly convex, but usually with a distinct, albeit narrow, shoulder such that suture is indented; sculpture of closeset, prosocline, axial ribs. Aperture roundly quadrate, peristome flaring, almost complete, interrupted only behind parietal lamella; apertural dentition 5-fold (Fig. 1C): 1) a strong, vertical, slightly oblique parietal lamella; 2) a large mid-labral complex, itself with three smaller teeth, a simple peg-like upper one and below this a larger, in-running ridge with a large, roundly trigonal tooth at its outer end and a smaller one at its inner end, large outer tooth sometimes with an additional weak cusp on its lower margin; 3) a roundly trigonal basal tooth to left of centre; 4) a more deep-set, transverse, ridge-like, tooth (sometimes with two cusps) between basal tooth and mid-labral complex; 5) a large quadrate columella lamella with three denticles, the upper one usually horizontal and somewhat ridge-like, the middle one protruding furthest into aperture. In addition to the above, there may be a small sinular denticle delimiting a shallow notch behind parietal lamella. Mid-labral complex marked externally by a deep pit behind flared outer lip; a smaller pit underlies basal tooth; columella lip smooth. A juvenile of 2.25 teleoconch whorls exhibited a very small tooth on the upper columella lip and a larger, transverse mid-basal tooth (Fig. 1E). Umbilicus open, drop-shaped and of moderate size, opening laterally some distance behind flared columella lip (Fig. 1D). Shell milky-white when fresh, usually with some superficial soil debris, particularly in sutural indentation.

Living ANIMAL. Head-foot yellow, optic retractor muscles bright orange.

RADULA. A single radula was available; corresponds to 'Group A' of Aiken (1981); formula $12+1+$ 12 ; length $\sim 2.7 \mathrm{~mm}$, with $87 \mathrm{~V}$-shaped rows of teeth; total number of teeth $\sim 2175$; rachidian extremely small; inner eight laterals of more or less equal size (3-7 slightly larger) with stout, blade-like cusp; base-plate with an oblique anchoring peg; outer laterals progressively smaller, the twelfth minute.

Distal Genitalia (Fig. 2). Penis of moderate length ( $\sim 3.5 \mathrm{~mm})$, subcylindrical, slightly broader distally, but somewhat constricted at junction with genital atrium; penial retractor undivided and attached to small penial caecum at penis apex. Lumen of penis with a single longitudinal pilaster running from area adjacent to penial caecum to base of penis; also with a raised subcircular pilaster near penis base; remainder of lumen with some weaker longitudinal folds and faint superficial striae; penial armature 
restricted to a small number of minute, trigonal hooks on apical portion of longitudinal pilaster. Vas deferens inserts laterally about halfway along penis, running toward penis base, then recurving along vagina and fusing with base of spermoviduct; vas deferens loosely adherent to penis base, but not fused to it; no evidence of a penis sheath or epiphallus. Atrium simple; vagina short and thin-walled; duct of gametolytic sac (bursa copulatrix) long, following course of spermoviduct to region of albumen gland; gametolytic sac itself narrow and elongate, scarcely broader than its duct; prostatic and oviductal portions of spermoviduct distinct; proximal portion of reproductive tract damaged and largely missing, but large fertilisation pouch-spermathecal complex remaining.

\section{Distribution}

A narrow-range endemic, currently recorded only from Mariepskop Forest Reserve on the edge of the Drakensberg Escarpment in northern Mpumalanga, South Africa; at altitudes from 1520 to $1700 \mathrm{~m}$.

\section{Habitat}

Northern mist-belt forest (Mucina \& Rutherford 2006), in leaf-litter.

\section{Remarks}

The size and overall facies of the shell is similar to that of G. johannae Bruggen, 2006 from the neighbouring Wolkberg massif. That species, like G. davisae sp. nov., has an almost complete peristome, interrupted only behind the parietal lamella and similar apertural dentition in the juvenile. However, the adult apertural dentition of the present species differs considerably from that of $G$. johannae. In the latter this dentition is less complex, the mid-labral tooth is essentially a single entity rather than a complex of three denticles, there is no deep-set, ridge-like tooth to the right of the basal tooth and the columella lamella is a simple horizontal tooth. In addition, the shell of $G$. johannae attains a slightly larger size (height up to $7.7 \mathrm{~mm}$ ), is somewhat more slender (H:D 2.16-2.88), and the umbilicus is wider and basally orientated. G. vicina luci Bruggen, 1980, from the eastern highlands of Zimbabwe, also has a

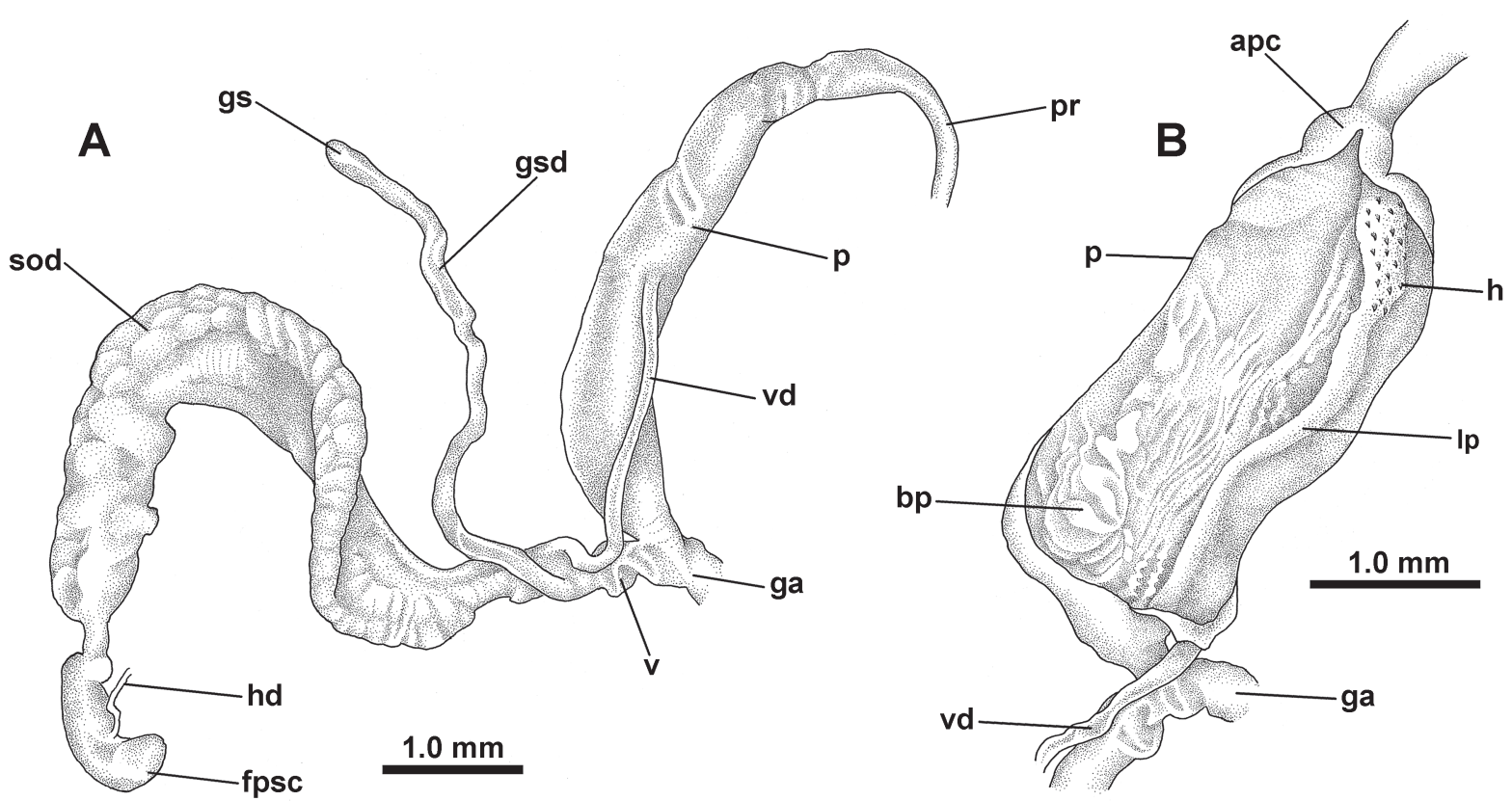

Fig. 2. Gulella davisae sp. nov., genitalia, paratype (NMSA P0269/T4090). A. Distal portion of genital system. B. Internal structure of penis. 
ribbed shell and tricuspid labral and columella teeth, but it is larger (height $8-9 \mathrm{~mm}$ ), has distinct spiral sculpture on the protoconch and its peristome is broadly interrupted in the parietal region.

The almost complete peristome shared by G. davisae sp. nov. and G. johannae is an unusual feature suggesting that the two are closely related and perhaps not members of Gulella s.s. Given that they occur in similar habitats on neighbouring mountain blocks, it seems likely that they are sister taxa derived from an ancestral stock that occurred on both blocks when forest cover was more extensive. G. herberti Bruggen, 2004, from southern Mpumalanga and Swaziland, is another species with a similar peristome, but its shell is smaller (height ca $4.0 \mathrm{~mm}$ ) and more globose, has a closed umbilicus and less complex apertural dentition. In G. herberti the peristome is almost completely detached from the preceding whorl, a condition taken to the extreme in G. salpinx Herbert, 2002 from southern KwaZulu-Natal. Herbert (2002) noted the similarities between G. salpinx and the Mascarene genus Microstrophia Möllendorff, 1887, and Rowson (2010) observed that both possess needle-like spines in the apical part of the penis. Subsequent molecular work (Rowson \& Herbert 2016) has shown that G. salpinx and Microstrophia are indeed related and that they cluster together with species of Primigulella and Dadagulella rather than in Gulella s.l. However, such needle-like penial spines are not evident in G. davisae sp. nov., suggesting that the apertural similarities might be superficial or convergent. The structure of the distal genitalia of G. davisae sp. nov. is unremarkable and is broadly comparable to that of many species of Gulella s.l. Similarly, its 'Group A' radula is the most common type of radula in Gulella s.l. and thus neither the radula nor the distal genitalia provide significant data regarding the relationships of the species. Further clarity in this regard must await analysis of molecular data and for the meantime I simply refer the species to Gulella s.l.

Gulella hadroglossa sp. nov.

urn:1sid:zoobank.org:act:B0429B6A-4C92-40BB-B2E7-A707A32ADE96

Fig. 3

\section{Etymology}

From hadros (Gr.) 'well-developed, great, strong', and glossa (Gr.) 'tongue'; referring to the large, tongue-like parietal lamella.

\section{Material examined}

\section{Holotype}

SOUTH AFRICA: Mpumalanga, Mariepskop Forest Reserve, Picnic Trail, $24.56847^{\circ} \mathrm{S}, 30.85920^{\circ} \mathrm{E}$, 1545 m, northern mist-belt forest, in leaf-litter, D. Herbert, L. Davis \& M. Cole, stn 14-27, 4 Dec. 2014, height $3.0 \mathrm{~mm}$, diameter $1.5 \mathrm{~mm}$ (NMSA P0230/T4084, dry specimen).

\section{Paratypes}

SOUTH AFRICA: Mpumalanga, same data as holotype (NMSA P0417/T4085, five dry specimens; NHMUK 20160038, one dry specimen; RMNH.5004142, one dry specimen); Mariepskop Forest Reserve, $24.55117^{\circ} \mathrm{S}, 30.89395^{\circ} \mathrm{E}, 1460 \mathrm{~m}$, indigenous Afromontane forest, in leaf-litter on forest floor, J.L. Horn, 23 Apr. 2005 (NMSA W3500/T4081, four dry specimens); Mariepskop Forest Reserve, Bushpig Trail, $24.56795^{\circ} \mathrm{S}, 30.86138^{\circ} \mathrm{E}, 1520 \mathrm{~m}$, northern mist-belt forest, in leaf-litter, D. Herbert, L. Davis \& M. Cole, stn 14-22a, 3 Dec. 2014 (NMSA P0263/T4082, one dry specimen); Mariepskop Forest Reserve, east facing slope, $24.57108^{\circ} \mathrm{S}, 30.86014^{\circ} \mathrm{E}, 1519 \mathrm{~m}$, leg. M. Cole, 18 Oct. 2010 (ELM D16635/T033, three dry specimens); Mariepskop Forest Reserve, in forest beside road at 1520-1700 m, leg. M. Cole, 3-4 Dec. 2014 (ELM D18019/T034, six dry specimens). 


\section{Type locality}

SOUTH AFRICA: Mpumalanga, Mariepskop Forest Reserve, Picnic Trail, $24.56847^{\circ} \mathrm{S}, 30.85920^{\circ} \mathrm{E}$, $1545 \mathrm{~m}$.

\section{Identification}

A small species of Gulella with a smooth, glossy, pupiform shell and 3-fold apertural dentition including a very large, oblique, tongue-like parietal lamella projecting far beyond the peristome; a mid-labral plate, the upper edge of which forms a narrow ridge-like tooth that runs obliquely inward and downward; a horizontal in-running tooth at columella base.
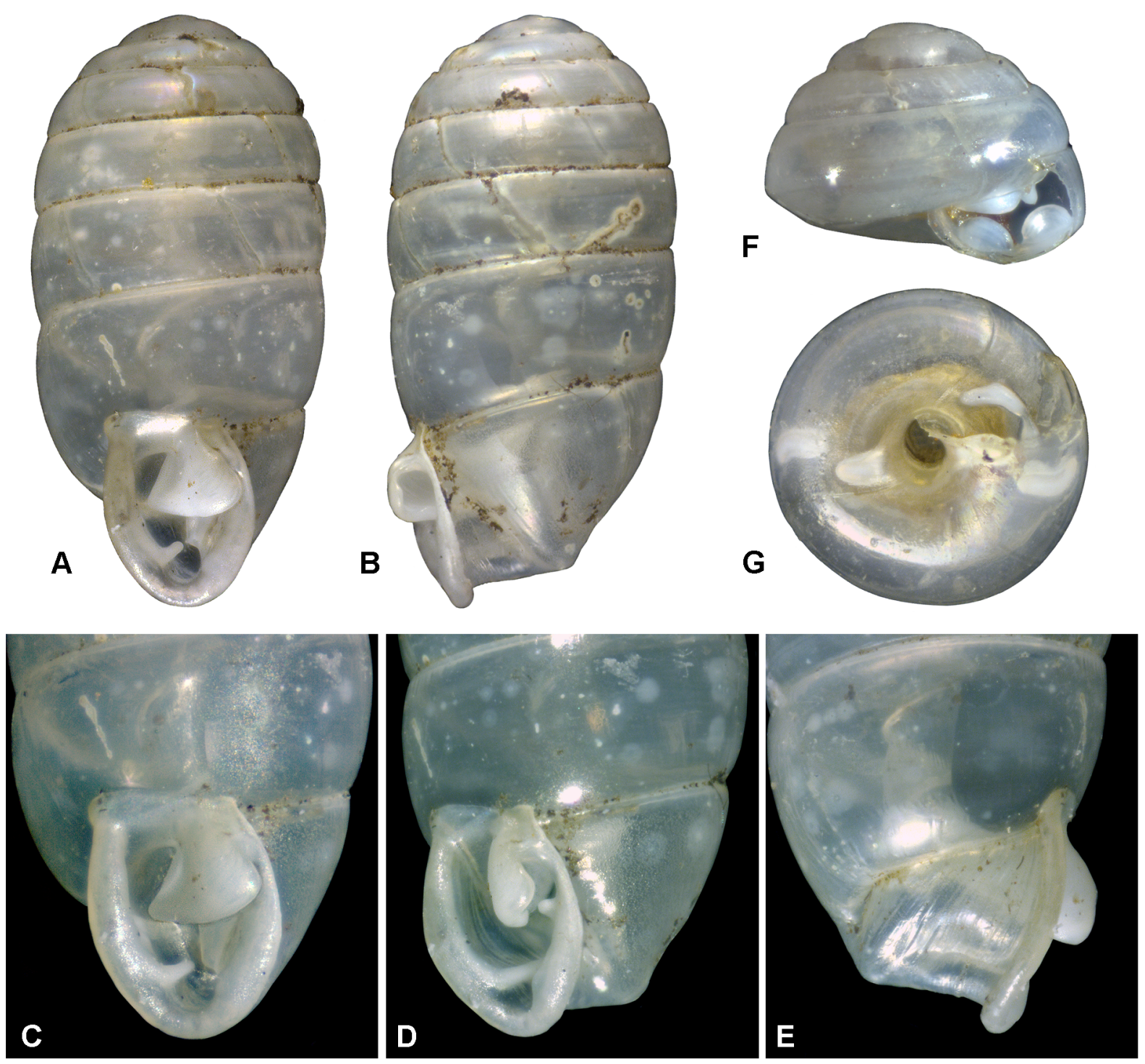

Fig. 3. Gulella hadroglossa sp. nov. A-E. Holotype, height $3.0 \mathrm{~mm}$, diameter $1.5 \mathrm{~mm}$ (NMSA P0230/ T4084). F-G. Juvenile specimen showing apertural dentition, diameter $1.5 \mathrm{~mm}$ (paratype, NMSA $\mathrm{P} 0417 / \mathrm{T} 4085)$. 


\section{Description}

SHELl (Fig. 3). Small, pupiform; adult height 3.0-3.1 mm, diameter 1.45-1.55 mm; H:D 1.96-2.09, with up to 7.25 whorls. Protoconch diameter $\sim 0.7 \mathrm{~mm}$, comprising $1.5-1.75$ whorls beyond nucleus, smooth and glossy when fresh; junction with teleoconch indistinct. Teleoconch comprising 5.0-5.5 whorls; whorls weakly convex, lacking a shoulder and suture weakly indented (may appear somewhat channelled in eroded specimens); smooth and glossy, sculptured only by occasional weak growthlines, some specimens with faint traces of subsutural pliculae (not evident in holotype); growth-lines stronger and more close-set on apertural tube behind peristome. Aperture ovate, but truncated where peristome interrupted in parietal region; aperture rim flaring and strongly recurved, forming a nearly closed channel behind lip; apertural dentition 3-fold (Fig. 3C-D): 1) a very large parietal lamella with a tongue-like anterior element that curves outward and to the right, well beyond plane of aperture and then backward towards outer lip; interval between lamella and outer lip partially filled with an overarching shelf, leaving a U-shaped notch behind lamella; 2) a mid-labral plate running inward from a low thickening of outer lip, its upper margin raised to form a narrow ridge that runs obliquely inward and downward (hidden by parietal lamella in frontal view), basal margin usually ill-defined; 3 ) a narrow in-running tooth near base of columella; a columella lamella is not evident, though in some specimens a very deep-set vertical ledge may be discerned where apertural tube kinks around to join rounded portion of last whorl. A juvenile specimen of $\sim 2.25$ teleoconch whorls possessed 4-fold apertural dentition (Fig. 3F-G) comprising: two well-developed, flattened, semi-circular teeth set transversely at left and right of basal lip, that on the right more deep-set; a curved parietal tooth just beyond limit of aperture, behind and to the right of which arises a fourth, more rounded tooth; a second, identical set of teeth visible by transparency one half-whorl behind aperture. Umbilicus closed, base grooved beneath basal columella tooth (Fig. 3E). Empty shells translucent greyish-white when fresh; yellow colour of dried body showing through in live-collected material.

LIVING ANIMAL. No preserved specimens available.

\section{Distribution}

A narrow-range endemic, currently recorded only from Mariepskop Forest Reserve on the edge of the Drakensberg Escarpment in northern Mpumalanga, South Africa; at altitudes from 1460 to $1545 \mathrm{~m}$.

\section{Habitat}

Northern mist-belt forest (Mucina \& Rutherford 2006), in leaf-litter.

\section{Remarks}

Gulella hadroglossa sp. nov. is rendered distinctive amongst small, smooth-shelled Gulella species on account of its large recurved parietal lamella. It is comparable in size (slightly smaller) and superficially similar to G. verdcourti Bruggen, 1966, from the neighbouring Wolkberg massif, but that species has a distinct subsutural shoulder resulting in an incised suture, and its apertural dentition is also different, the parietal lamella not projecting as far and the mid-labral tooth being stronger.

Family Urocyclidae Simroth, 1889

Ptilototheca gen. nov. urn:1sid:zoobank.org:act:51C2C9E7-9514-43DF-A09B-3E391D3B61DD

\section{Type species}

Ptilototheca soutpansbergensis gen. et sp. nov. 


\section{Diagnosis}

Shell small, delicate and glossy, periphery below mid-whorl, base narrowly umbilicate; protoconch with close-set spiral lines of small punctations. Epiphallus very short, flagellum squat, vas deferens long, thickened and convoluted, penial verge present; spermatophore tail with well-developed, finely divided, branching spines.

\section{Etymology}

From ptilon, ptilotos (Gr.) a 'feather, feathered' and theca (L.) a 'case or container'; referring to the plumose ornamentation of the spermatophore. Gender feminine.

\section{Remarks}

Within a southern African context, the spirally punctate protoconch of Ptilototheca gen. nov. might suggest an affinity with Sheldonia s.s., but the distal genitalia of the present species are quite distinct and clearly discount any close relationship between the two. Although few other southern African heliciform urocyclids possess such a protoconch, the character is commonly present in semi-slug genera from further north in Africa (Van Mol 1970). In terms of its distal genital anatomy, P. soutpansbergensis gen. et sp. nov. is unlike any other southern African heliciform urocyclid species. The extremely short epiphallus, short squat flagellum, ornately bristled spermatophore and long, thick, convoluted vas deferens are distinctive characters not seen in other species from the region. In addition, the presence of a penial verge and a papillate preputial region are also unusual features among local species, but these are also present in $S$. wolkbergensis sp. nov. (see below). That species, however, lacks a spirally punctate protoconch, possesses an atrial diverticulum, has a short, slender, non-convoluted vas deferens, and an epiphallus and flagellum of more conventional length for Sheldonia s.l. Species of the central African semi-slug genus Angustivestis Pilsbry, 1919 also possess a penial verge and a papillate preputial region, as well as a long, thick, convoluted vas deferens, but again in that genus the protoconch is not spirally punctate, the epiphallus and flagellum not conspicuously shortened and there is usually an atrial diverticulum (Van Mol 1970). Considered collectively, the conchological and anatomical features exhibited by $P$. soutpansbergensis gen. et sp. nov. strongly suggest that it is not closely related to other southern African heliciform urocyclids and that it belongs to a distinct lineage that may perhaps have closer affinities with central African genera. Its distribution in the extreme north of South Africa is consistent with this.

Helicarion pumilio Melvill \& Ponsonby, 1909, the type species of Andrarion Godwin-Austen, 1912, was also described from the Soutpansberg. This remains a poorly known and enigmatic species, but it differs from the present material in having a smaller, more depressed shell with a smooth protoconch and a rapidly expanding last whorl [confirmed by examination of the type material: lectotype (des. Connolly 1912: 101) NHMUK 1910.1.5.12 (maj. diameter $6.8 \mathrm{~mm}$ ) and three paralectotypes NHMUK 1937.12.30.4113-5]. The original specimens remain the only material available and I strongly suspect that they are simply juveniles of a larger species of Sheldonia (Kerkophorus), at least one species of which occurs in the Afrotemperate forests of Limpopo. This remains a matter requiring further investigation, but for the present it is sufficient to confirm that the material discussed herein is undoubtedly distinct from H. pumilio.

Ptilototheca soutpansbergensis gen. et sp. nov. urn:1sid:zoobank.org:act:F3F6A7DF-A655-483B-9865-AB0AA56DCCE8

Figs $4-8$

\section{Etymology}

Named after the Soutpansberg massif, to which the species is endemic. 


\section{Material examined}

\section{Holotype}

SOUTH AFRICA: Limpopo, Soutpansberg, Sibasa area, Phiphidi Falls, $22.9483^{\circ} \mathrm{S}, 30.3950^{\circ} \mathrm{E}, \sim 1000 \mathrm{~m}$, indigenous forest, in leaf-litter, D. Herbert, 20 Nov. 1997, diameter $9.2 \mathrm{~mm}$, height $6.1 \mathrm{~mm}$ (NMSA V5567/T4069, body in ethanol).

Paratypes (listed west to east)

SOUTH AFRICA: Limpopo, Soutpansberg, Hanglip Forest, picnic site, $22.99951^{\circ} \mathrm{S}, 29.88643^{\circ} \mathrm{E}$, $1540 \mathrm{~m}$, northern mist-belt forest, in leaf-litter, leg. D. Herbert, L. Davis \& M. Cole, stn 14-14, 29 Nov. 2014 (NMSA P0214/T4070, three specimens, body of one in ethanol); Hanglip Forest, $23.017^{\circ} \mathrm{S}, 29.900^{\circ} \mathrm{E}$, indigenous forest, J. Swaye, Mar. 2001 (NMSA V9485/T4071, five dry specimens; ELM D18041/T039, one dry specimen); Goedehoop Forest, $23.067^{\circ} \mathrm{S}, 30.121^{\circ} \mathrm{E}, 1250 \mathrm{~m}$, sorted from leaf-litter, C. Symes, 30 Oct. 1999 (NMSA V7506/T4066, six dry specimens); Entabeni Forest, $22.99092^{\circ} \mathrm{S}, 30.27829^{\circ} \mathrm{E}$, Afromontane forest, in leaf-litter, J. Swaye, L91, L95, Oct.-Nov. 2001 (NMSA W2259/T4067, nine dry specimens, seven in ethanol); Entabeni Forest, environs of Kliphuis, $22.98589^{\circ} \mathrm{S}, 30.28127^{\circ} \mathrm{E}$, 1345 m, northern mist-belt forest, in leaf-litter, D. Herbert, L. Davis \& M. Cole, stn 14-17, 30 Nov. 2014 (NMSA P0183/T4068, 11 specimens, bodies of five in ethanol; NHMUK 20160040, one dry specimen; RMNH.5004144, one dry specimen); Entabeni Forest, environs of Kliphuis, $22.98455^{\circ} \mathrm{S}, 30.28272^{\circ} \mathrm{E}$, 1365 m, northern mist-belt forest, in leaf-litter, D. Herbert, L. Davis \& M. Cole, stn 14-16, 30 Nov. 2014 (NMSA P0186/T4063, 10 specimens, bodies of five in ethanol); Thathe Vondo Forest, $22.87705^{\circ} \mathrm{S}$, $30.35026^{\circ}$ E, Afromontane forest, in leaf-litter, J. Swaye, L41, Oct.-Nov. 2001 (NMSA W2080/T4064, 18 dry specimens, two in ethanol); Thathe Vondo Forest, near sacred shrine, $22.92649^{\circ} \mathrm{S}, 30.35270^{\circ} \mathrm{E}$, 1075 m, northern mist-belt forest, in leaf-litter, D. Herbert, L. Davis \& M. Cole, stn 14-18, 1 Dec. 2014
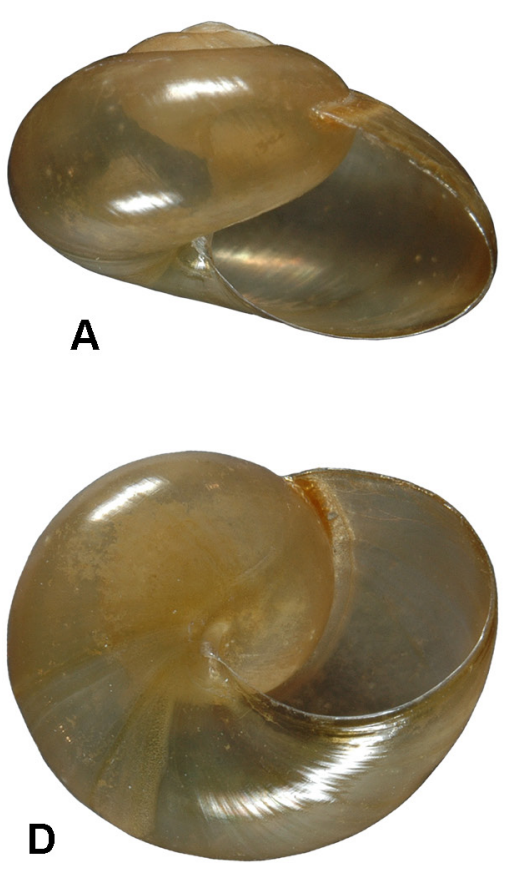
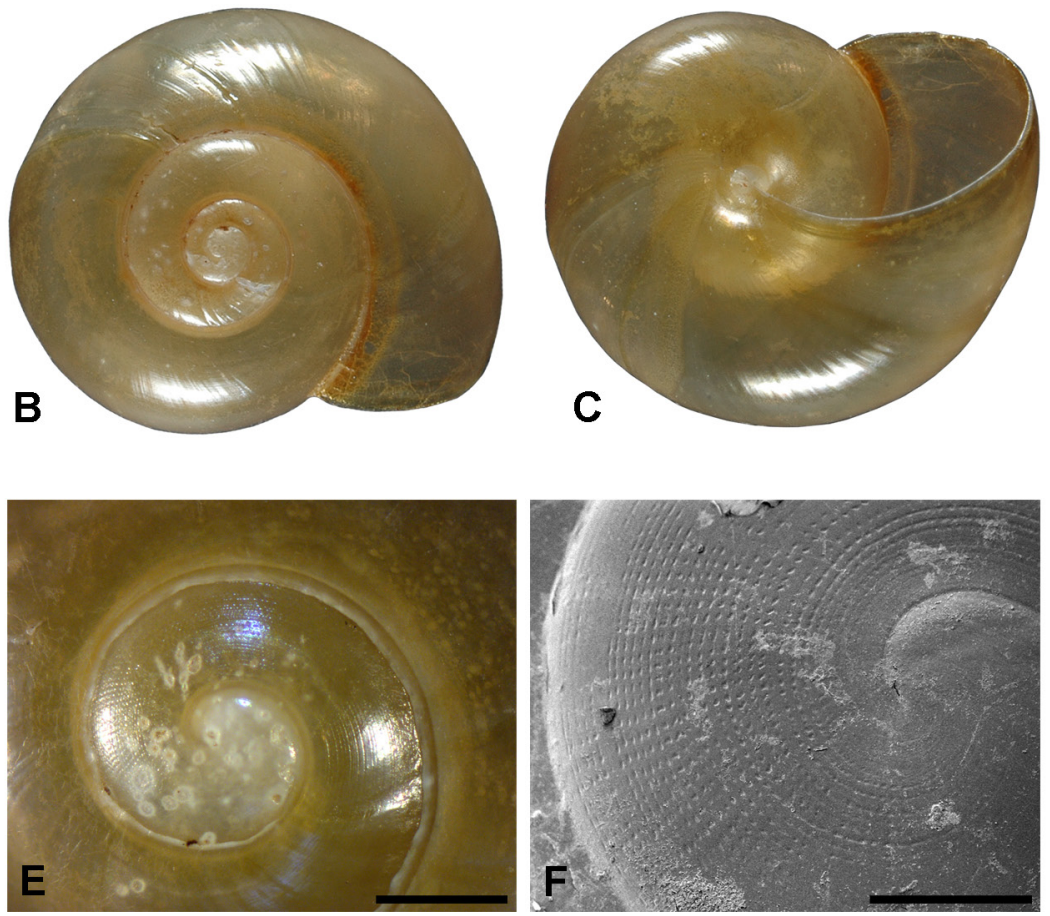

Fig. 4. Ptilototheca soutpansbergensis gen. et sp. nov. A-D. Holotype, diameter 9.2 mm (NMSA V5567/ T4069). E. Protoconch showing sculpture of punctate spiral lines, Entabeni Forest (paratype, NMSA P0186/T4063). F. SEM of protoconch microsculpture, Thathe Vondo Forest (paratype, NMSA W2080/ T4064). Scale bars: $\mathrm{E}=0.5 \mathrm{~mm} ; \mathrm{F}=250 \mu \mathrm{m}$. 
(P0225/T4065, one specimen, body in ethanol; ELM D18049/T040, one dry specimen); Thathe Vondo Forest, near sacred shrine, $22.92173^{\circ} \mathrm{S}, 30.35760^{\circ} \mathrm{E}, 1090 \mathrm{~m}$, northern mist-belt forest, in leaf-litter, D. Herbert, L. Davis \& M. Cole, stn 14-19, 1 Dec. 2014 (NMSA P0304/T4060, two specimens, body of one in ethanol).

Other material (listed west to east, all in NMSA)

SOUTH AFRICA: Limpopo, Soutpansberg, Dundee Forest, $23.017^{\circ} \mathrm{S}, 29.515^{\circ} \mathrm{E}, 1525 \mathrm{~m}$, sorted from leaf-litter, C. Symes, 24 Jul. 1999 (V7516); Hanglip Forest, 23.00002 ${ }^{\circ}$ S, 29.88789 ${ }^{\circ}$ E, $1360 \mathrm{~m}$, mist-belt forest, in leaf-litter, A. Moussalli \& D. Stuart-Fox, 16 Dec. 2006 (W5637); Hanglip Forest, $23.017^{\circ} \mathrm{S}, 29.900^{\circ}$ E, 1370 m, A.C. \& W.H. van Bruggen, Feb. 1965 (A8342); Entabeni Forest, $23.013^{\circ} \mathrm{S}, 30.080^{\circ} \mathrm{E}, 1175 \mathrm{~m}$, sorted from leaf-litter, C. Symes, 16 Jul. 1999 (V7494); Goedehoop Forest, $23.07253^{\circ} \mathrm{S}, 30.11494^{\circ} \mathrm{E}, 1190 \mathrm{~m}$, Afromontane forest, in leaf-litter, J. Swaye, L59, Oct.-Nov. 2001 (W2064); Entabeni Forest, 23.000 ${ }^{\circ} \mathrm{S}, 30.233^{\circ} \mathrm{E}$, indigenous forest, J. Swaye, L19a, Mar. 2001 (V9475); Entabeni, Matiwa Kop, $22.983^{\circ} \mathrm{S}, 30.250^{\circ} \mathrm{E}, 1310 \mathrm{~m}$, in forest, A.C. \& W.H. van Bruggen, Feb. 1965 (A8352); Entabeni Forest, $22.983^{\circ}$ S, $30.250^{\circ}$ E, 1160 m, A.C. \& W.H. van Bruggen, Feb. 1965 (A8341); Entabeni Forest, 22.99541 ${ }^{\circ} \mathrm{S}, 30.28023^{\circ} \mathrm{E}$, Afromontane forest, in leaf-litter, J. Swaye, L30, Feb.-Mar. 2001 (W2261); Thathe Vondo Forest, 22.872933 S, $30.338783^{\circ} \mathrm{E}, 1280 \mathrm{~m}$, indigenous Afromontane forest, in leaf-litter, J. Horn, 1 Mar. 2006 (W7717); Thathe Vondo Forest, 22.876 ${ }^{\circ} \mathrm{S}$, $30.349^{\circ} \mathrm{E}, 1430 \mathrm{~m}$, indigenous forest, in leaf-litter, C. Symes, 4 Nov. 1999 (V7639).

\section{Type locality}

SOUTH AFRICA: Limpopo, Soutpansberg, Sibasa area, Phiphidi Falls, 22.9483 S, 30.3950 E, $\sim 1000 \mathrm{~m}$.

\section{Identification}

Easily identified on account of the fact that it is the only heliciform urocyclid occurring in the Soutpansberg that has a spirally punctate protoconch. Additional distinctive anatomical characters are given in the generic diagnosis above.

\section{Description}

SHELl (Fig. 4). Small, globose-lenticular, largest specimen with diameter $10.0 \mathrm{~mm}$, height $4.9 \mathrm{~mm} ; \mathrm{H}: \mathrm{D}$ 0.62-0.71; periphery below mid-whorl, evenly rounded; suture indented, but not strongly so, inserting
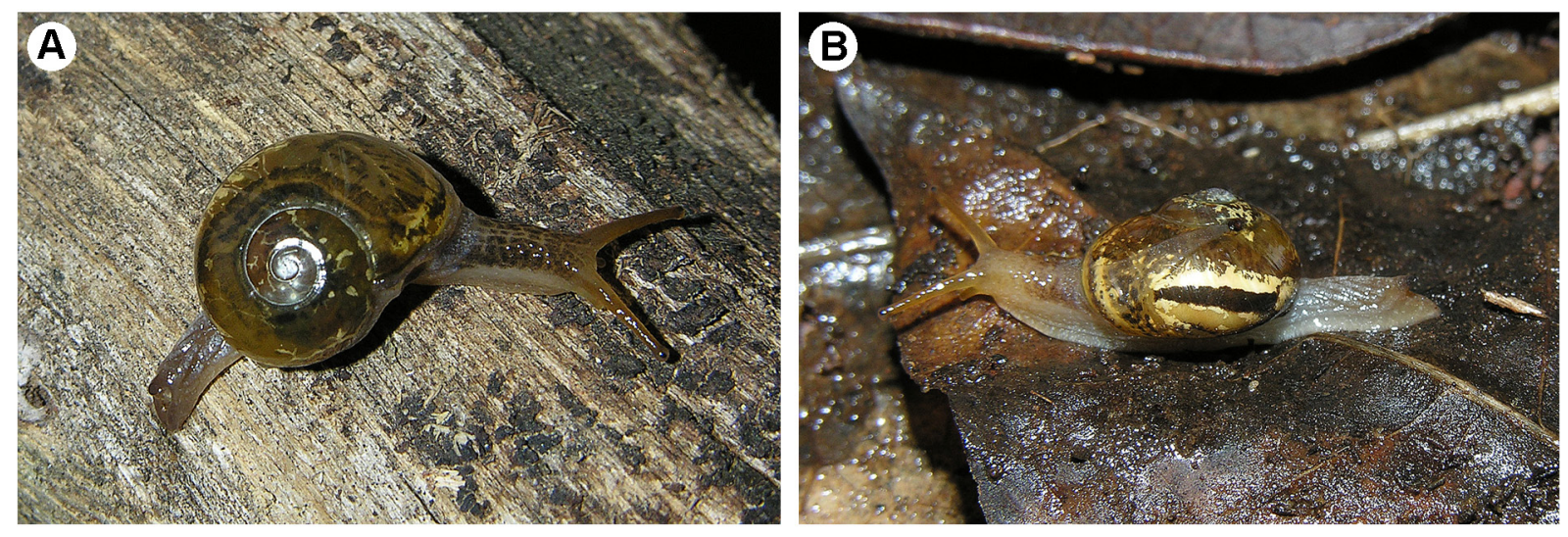

Fig. 5. Ptilototheca soutpansbergensis gen. et sp. nov., living animals, Entabeni Forest, Soutpansberg, Limpopo. A. Darkly pigmented individual, shell diameter $8.4 \mathrm{~mm}$ (paratype, NMSA P0186/T4063). B. Paler individual showing contrasting pigmentation overlying the renal area, shell diameter $8.0 \mathrm{~mm}$ (paratype, NMSA P0183/T4068). 
above periphery; very thin and delicate. Protoconch diameter 1.1-1.4 mm; junction with teleoconch weakly marked; nucleus more or less smooth, but protoconch thereafter with numerous microscopic punctations arranged in close-set spiral lines (Fig. 4E-F), also with some collabral alignment; in last quarter whorl punctations coalesce to form fine incised spiral lines. Teleoconch of up to 2.5 whorls; whorl expansion moderate; sculptured with fine, close-set, microscopic spiral striae, relatively weak on first whorl but strengthening and relatively distinct from start of second whorl onward; teleoconch otherwise only with weak, uneven growth irregularities. Columella concave, adapical region whitish and reflected over umbilical region and fused to adjacent part of base, forming a distinct umbilical channel; aperture obliquely lunate. Translucent, more or less uniformly yellowish-brown; apical and basal surfaces both glossy.

EXTERNAL FEATURES (Fig. 5). Head and neck usually dark grey dorsally, pale greyish-white ventrally; grey pigmentation associated with skin granules and thus appearing as dense spotting; pigmentation weaker in some specimens; tentacles brownish-grey, yellowish-brown in pale individuals; posterior of foot more uniformly grey, caudal appendage somewhat darker. Body lobes of mantle edge grey; right and left shell lobes elongate-trigonal to spathulate when extended over shell, pale and translucent; posterior of foot and mantle lobes with scattered, minute, bluish-grey pigment granules. Pulmonary lining behind mantle edge variously bordered with cream and black pigmentation, often as collabral bands; additional dark blotches and lines posterior to this, with a very prominent and well-defined black band overlying primary ureter, to the right of pale tissues of kidney, sometimes with a further well-defined line of cream pigment to the right of (i.e., dorsal to) black band (Fig. 5B). Spire viscera dark brown with irregularly
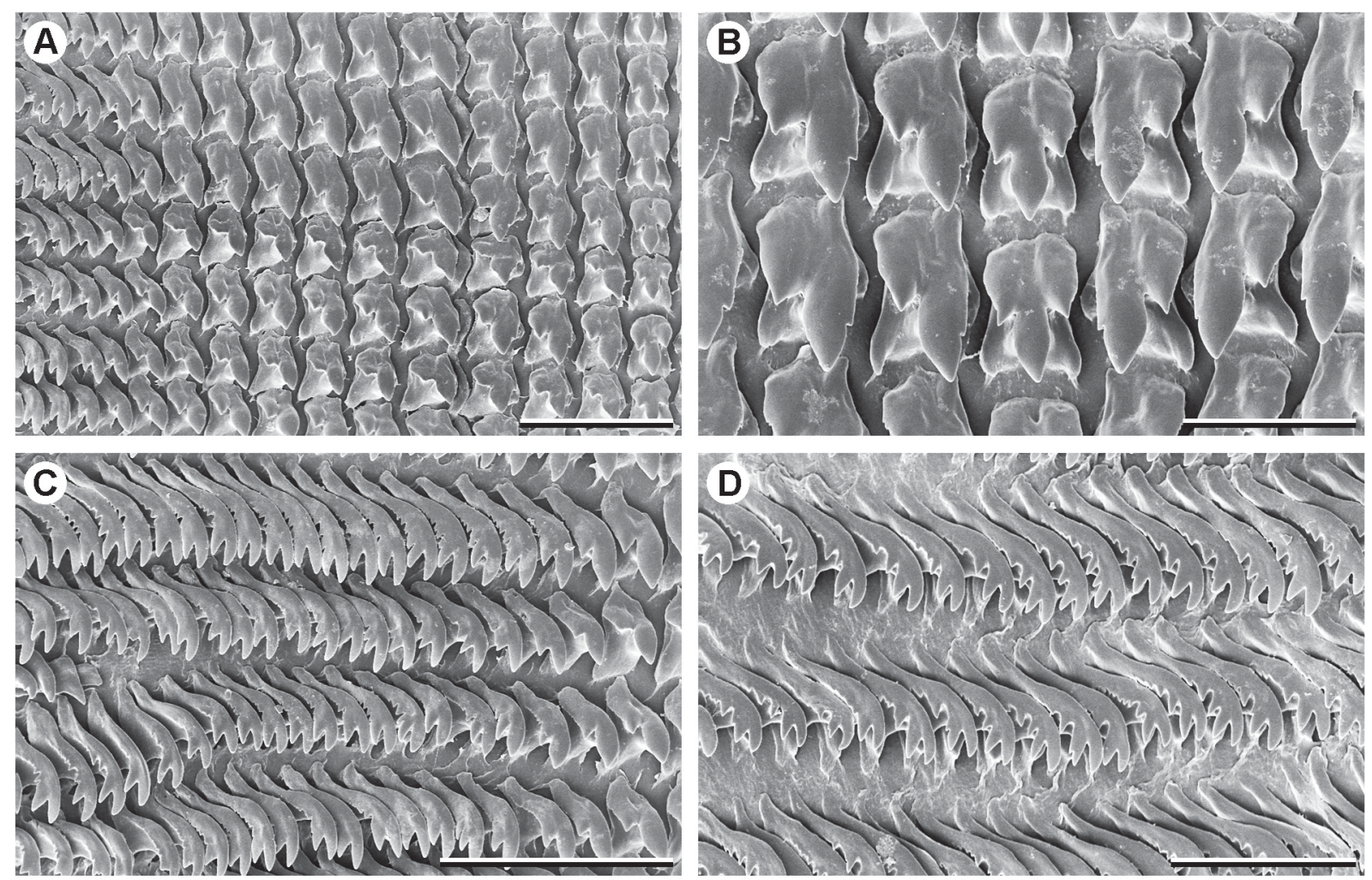

Fig. 6. Ptilototheca soutpansbergensis gen. et sp. nov., radula, holotype (NMSA V5567/T4069). A. Rachidian and left lateral teeth. B. Rachidian and innermost lateral teeth. C. Inner left marginal teeth. D. Outer left marginal teeth. Scale bars: A, C $=50 \mu \mathrm{m} ; \mathrm{B}, \mathrm{D}=25 \mu \mathrm{m}$. 
branching, cream venation, usually sparse and sometimes virtually absent. Caudal pit and appendage well developed.

Radula (Fig. 6). Formula R+9+(1-2)+(70-80); rachidian tricuspid, laterals essentially bicuspid with a mesocone and strong basal ectocone, but also with a minute endocone on side of mesocone; laterals followed by 1-2 intermediary teeth and then a long series of marginals; marginals curved and terminally bicuspid, but with a series of smaller cusps or serrations on concave outer edge, these proportionately stronger on smaller teeth toward radula margin.

Distal genitalia (Fig. 7). Penis cylindrical, tapering toward apex, surrounded in a thin sheath, occasionally slightly kinked in mid region; penis divided into two portions, a thick muscular apical region ( $\sim 3 / 4$ of penis length) ending at a conical penial verge, and a basal thinner-walled preputial region lined internally by coarse rounded papillae (Fig. 7B). Epiphallus extremely short, with a small caecum arising close to penis-epiphallus junction; retractor muscle attached to penis apex, close to base of caecum. Flagellum very short and squat, divided into F1 and F2, but not sharply so (Fig. 7C); F1 broad basally, twisted into approximately one revolution, internal diverticulae poorly delineated; F2 a small papilla-like structure at tip of F1, internal diverticulae more visible. Vas deferens long, thick and much convoluted in proximal portion between base of spermoviduct and penis base; inserts at junction of

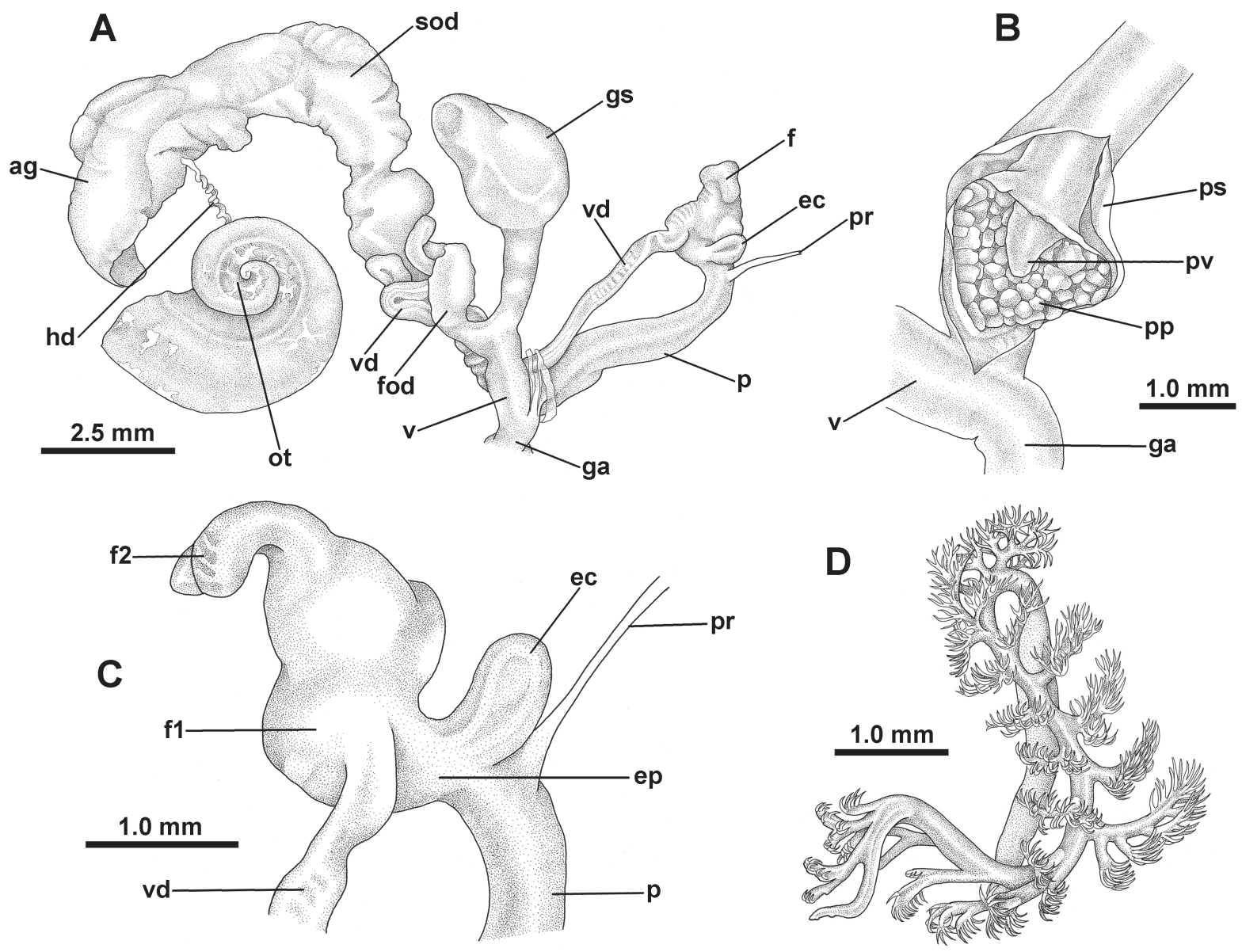

Fig. 7. Ptilototheca soutpansbergensis gen. et sp. nov., genitalia. A. Entire genital system. B. Basal portion of penis opened to show penial verge and coarsely papillate preputial region. C. Flagellum and epiphallus. D. Spermatophore. A-C. Paratype, NMSA P0304/T4060. D. Paratype, NMSA W2259/T4067. 
epiphallus and flagellum without evidence of chalky internal material. Genital atrium simple; vagina short; gametolytic sac capacious, its duct of moderate length; base of free oviduct somewhat swollen, pale apricot; spermoviduct divided into distinct prostatic and oviductal portions. Spermatophore elbowed (Fig. 7D), with a relatively slender capsule; most of tail with well-developed, fan-like spines with multiple branches (often in clumps), the tips finely pointed and recurved; tail initially relatively slender, but broader and more robust in mid-region; unbranched tip of tail very short.

\section{Distribution (Fig. 8)}

A narrow-range endemic, known only from the Soutpansberg massif, Limpopo, South Africa; at altitudes between 1000 and $1525 \mathrm{~m}$ above sea level.

\section{Habitat}

Northern mist-belt forest (Mucina \& Rutherford 2006); all material collected to date has been found in forest floor leaf-litter.

\section{Genus Sheldonia Ancey, 1887 (sensu lato)}

Sheldonia Ancey, 1887: 53. Type species: Helix trotteriana Benson, 1848, by subsequent designation (Connolly 1925: 467).

Peltatus Godwin-Austen, 1908: 131. Type species (original designation) Helix hudsoniae (non Benson, 1864) Godwin-Austen, 1908 [= Vitrina huttoniae var. aloicola Melvill \& Ponsonby, 1890, cf. GodwinAusten 1912].

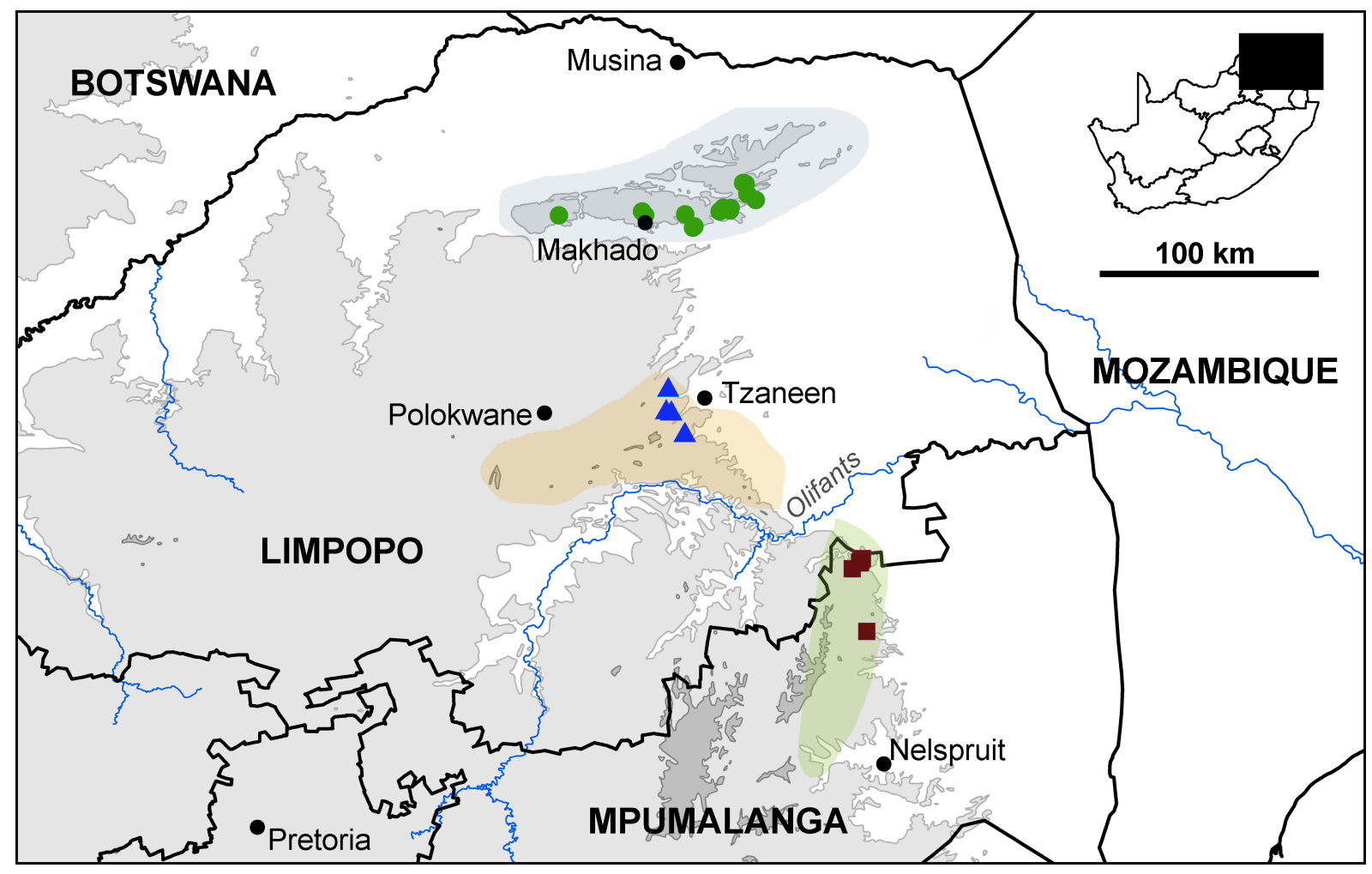

Fig. 8. Map showing the distribution of new urocyclid species in relation to centres of plant endemism (Van Wyk \& Smith 2001). Green circles = Ptilototheca soutpansbergensis gen. et sp. nov.; blue triangles $=$ Sheldonia wolkbergensis sp. nov.; maroon squares = Sheldonia monsmaripi sp. nov.; pale blue $=$ Soutpansberg Centre; pale orange $=$ Wolkberg Centre (Serala Subcentre); pale green $=$ Wolkberg Centre (Blyde Subcentre). Contours at 1000 and $2000 \mathrm{~m}$. 
Sheldonia is currently a poorly understood and ill-defined genus that has been used sensu lato for an assemblage of heliciform urocyclids occurring in southern Africa. Unpublished anatomical and molecular studies clearly show that it is a composite entity comprising several distinct, monophyletic lineages that warrant recognition as distinct genus-level entities. In Sheldonia s.s. the epiphallus is of moderate length, the epiphallic caecum is elongate and arises close to or just distal to the mid-region of the epiphallus, the flagellum is long and divided into distinct F1 and F2 components, the atrium frequently possesses a stimulator and the free oviduct gland is conspicuously enlarged. There is no penial verge or atrial diverticulum and the vas deferens is not thickened and convoluted. In addition, the protoconch is usually punctate.

The above is largely in accordance with the description of the genus given by Schileyko (2002), except that he stated that the penial retractor muscle was attached to the summit of the caecum when in reality it is attached to the penis apex. This discrepancy stems from the figure of the reproductive tract of S. hudsoniae provided by Godwin-Austen (1908) and was corrected in a subsequent paper (GodwinAusten 1912) in relation to this species and several others, including the type species. Following Connolly (1939), Schileyko (2002) treated Kerkophorus Godwin-Austen, 1912 and Microkerkus Godwin-Austen, 1912 as synonyms of Sheldonia, but ongoing studies indicate that this is an oversimplification. Further discussion of this is beyond the scope of the present contribution, but the morphological characters diagnostic of these taxa will be provided, together with a key, in a subsequent publication.

The following two species clearly do not belong to Sheldonia s.s., nor are they clearly referable to either Kerkophorus or Microkerkus. Their position relative to other southern African helicoid urocyclids is unclear and for the time being I refer them to Sheldonia in its broadest sense. Clarification of their affinities must await analysis of molecular data.

Sheldonia monsmaripi sp. nov. urn:1sid:zoobank.org:act:2C26E39F-EB96-4864-8F82-B7ABCBDD0F1F

Figs $8-12$

\section{Etymology}

From mons (L.) 'mountain' and Maripi in reference to Chief Maripi Mashile of the Bapedi tribe, after whom the type locality, Mariepskop, is named.

\section{Material examined}

\section{Holotype}

SOUTH AFRICA: Mpumalanga, Mariepskop Forest Reserve, $24.59563^{\circ} \mathrm{S}, 30.82600^{\circ} \mathrm{E}, 790 \mathrm{~m}$, indigenous riverine forest, in leaf-litter on forest floor, J. Horn, 25 May 2006, diameter $12.2 \mathrm{~mm}$, height $8.7 \mathrm{~mm}$ (NMSA W4413/T3300, body in ethanol).

\section{Paratypes}

SOUTH AFRICA: Mpumalanga, Mariepskop Forest Reserve, $24.563^{\circ} \mathrm{S}, 30.863^{\circ} \mathrm{E}, 1400 \mathrm{~m}$, indigenous Afromontane forest, A.C. \& W.H. van Bruggen, 29 Jan. 1966 (W3653/T3169, nine specimens, bodies in ethanol; ELM D18067/T151, one dry specimen); Mariepskop Forest Reserve, $24.56353^{\circ} \mathrm{S}, 30.86252^{\circ}$ E, $1620 \mathrm{~m}$, indigenous Afromontane forest, $3 \mathrm{~m}$ above ground in epiphytes of standing tree, J. Horn, stn L42, 22 May 2005 (NMSA W3679/T3170, one specimen, body in ethanol); Mariepskop Forest Reserve, $24.56374^{\circ} \mathrm{S}, 30.86293^{\circ} \mathrm{E}, 1640 \mathrm{~m}$, northern mist-belt forest, under Streptocarpus leaf on tree trunk, D. Herbert, L. Davis \& M. Cole, stn 14-22, 3 Dec. 2014 (NMSA P0276/T4073, one specimen, body in ethanol); Mariepskop Forest Reserve, Bushpig Trail, $24.56694^{\circ} \mathrm{S}, 30.86270^{\circ} \mathrm{E}, 1491 \mathrm{~m}$, mistbelt forest, A. Moussalli \& D. Stuart-Fox, 15 Dec. 2006 (NMSA W5741/T3171, one specimen, body in ethanol); Mariepskop Forest Reserve, $24.56708^{\circ} \mathrm{S}, 30.85990^{\circ} \mathrm{E}, 1540 \mathrm{~m}$, Afromontane forest, in 
Clivia cluster on live tree ca $1 \mathrm{~m}$ above ground, J. Horn, stn L64, 24 Nov. 2005 (NMSA W3900/T3172, six specimens, bodies in ethanol; NHMUK 20160039, one dry specimen; RMNH.5004143, one dry specimen); Mariepskop Forest Reserve, $24.56795^{\circ} \mathrm{S}, 30.86138^{\circ} \mathrm{E}, 1520 \mathrm{~m}$, Afromontane forest, in Clivia cluster on live tree, ca $1 \mathrm{~m}$ above ground, J. Horn, stn L64, 24 Nov. 2005 (NMSA W3899/T3173, four specimens, bodies in ethanol); Mariepskop Forest Reserve, Picnic Trail, $24.56847^{\circ} \mathrm{S}, 30.85920^{\circ}$ E, 1545 m, northern mist-belt forest, in leaf-litter, D. Herbert, L. Davis \& M. Cole, stn 14-27, 4 Dec. 2014 (NMSA P0228/T4072, five specimens, bodies of two in ethanol); Mariepskop Forest Reserve, $24.59563^{\circ} \mathrm{S}, 30.82600^{\circ} \mathrm{E}, 790 \mathrm{~m}$, indigenous riverine forest, in leaf-litter on forest floor, J. Horn, 25 May 2006 (NMSA W9581/T3301, one specimen, body in ethanol); God's Window, $24.8746^{\circ} \mathrm{S}$, $30.8909^{\circ} \mathrm{E}$, Afromontane forest, active on understorey foliage, A. Moussalli \& D. Stuart-Fox, 25 Feb. 2004 (NMSA W3335/T3178, two specimens, bodies in ethanol); God's Window, $24.875^{\circ} \mathrm{S}, 30.891^{\circ} \mathrm{E}$, rainforest, W. Haselau, Mar. 2006, don. M. Bursey (NMSA W4858/T3179, three specimens, bodies in ethanol).

\section{Other material}

SOUTH AFRICA: Mpumalanga, Mariepskop summit, $24.54933^{\circ} \mathrm{S}, 30.87170^{\circ} \mathrm{E}, 1920 \mathrm{~m}$, rocky Afromontane fynbos, in leaf-litter, D. Herbert, L. Davis \& M. Cole, stn 14-21, 3 Dec. 2014 (NMSA P0278); Mariepskop, just below summit, $24.55649^{\circ} \mathrm{S}, 30.86662^{\circ} \mathrm{E}, 1830 \mathrm{~m}$, Afromontane fynbos/ forest border, in leaf-litter beneath Clivia plants, D. Herbert, L. Davis \& M. Cole, stn 14-25, 4 Dec. 2014 (NMSA P0255).

\section{Type locality}

SOUTH AFRICA: Mpumalanga, Mariepskop Forest Reserve, $24.59563^{\circ} \mathrm{S}, 30.82600^{\circ} \mathrm{E}, 790 \mathrm{~m}$.
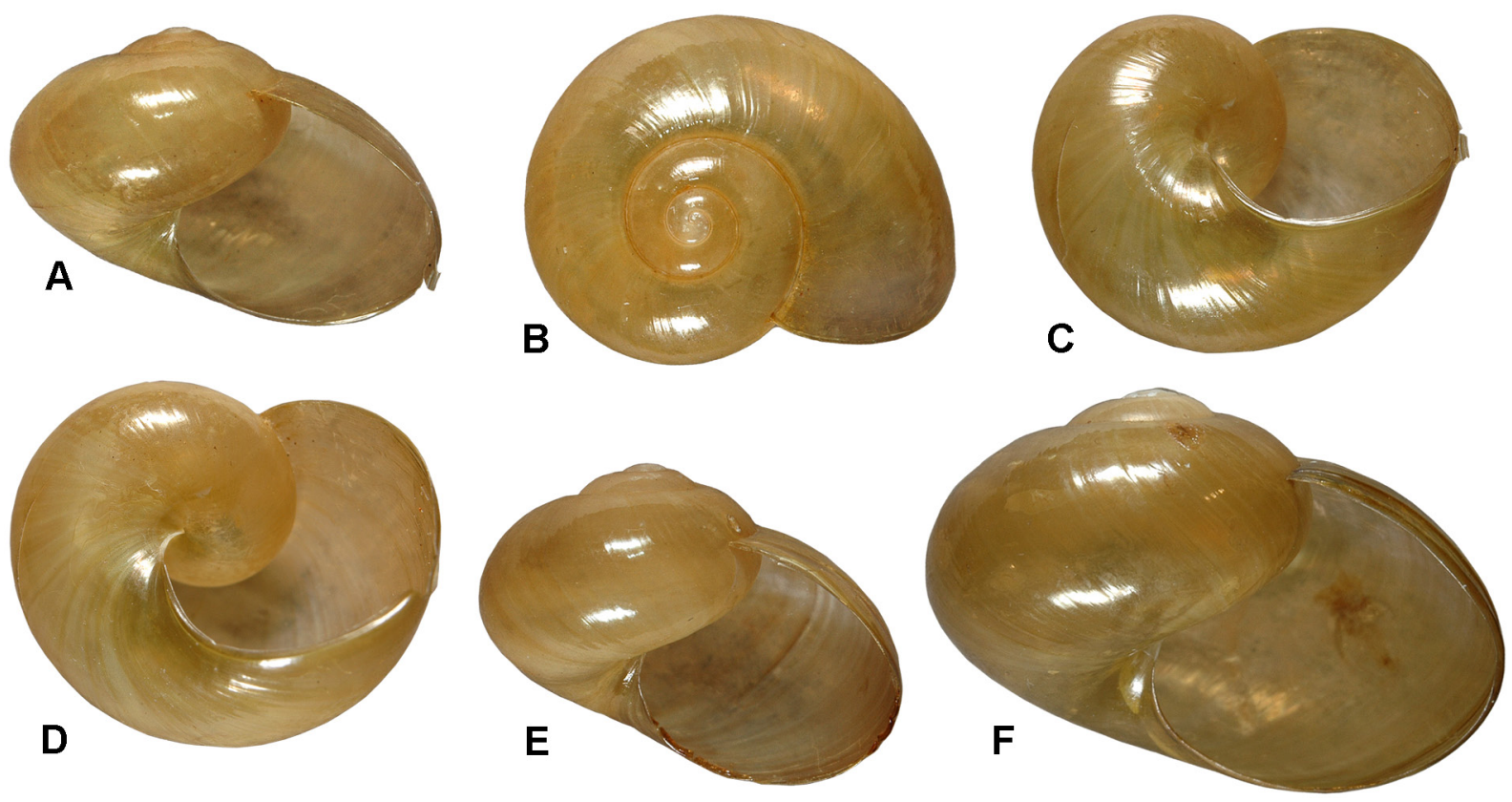

Fig. 9. Sheldonia monsmaripi sp. nov. A-D. Holotype, diameter $12.2 \mathrm{~mm}$ (NMSA W4413/T3300). E. Paratype, diameter $12.0 \mathrm{~mm}$ (NMSA W3900/T3172). F. Large specimen from fynbos on Mariepskop summit, diameter $16.4 \mathrm{~mm}$ (NMSA P0278). 


\section{Identification}

Characterised by a combination of shell and anatomical characters, notably the glossy, globose, uniformly yellowish-brown shell, smooth protoconch and non-rimate columella lip; distal genitalia with an atrial diverticulum, a gametolytic duct of moderate length, and a curved epiphallic caecum situated much closer to penial retractor than to insertion of vas deferens.

\section{Description}

SHELL (Fig. 9). Globose-lenticular to subglobose; diameter generally less than $13.0 \mathrm{~mm}$, but specimens from high altitude fynbos habitat reaching $18.0 \mathrm{~mm} ; \mathrm{H}: \mathrm{D} 0.68-0.75$; periphery close to mid-whorl, evenly rounded; suture shallowly but distinctly indented, inserting above periphery; very thin and delicate. Protoconch diameter 1.7-1.8 mm, junction with teleoconch indistinct; sculpture virtually smooth, with only traces of the finest microscopic scratch-like spiral lines. Teleoconch of up to 2.25 whorls; whorls expanding moderately rapidly; spiral sculpture virtually obsolete, some extremely fine traces of closeset, wavy, spiral lines, even weaker on base; teleoconch otherwise only with weak, uneven growth-lines, strongest below suture. Umbilicus absent, edge of columella lip whitish, reflected and somewhat raised, spiralling into axis of coiling rather than fusing with parietal region; aperture sub-circular. Translucent, more or less uniformly yellowish-brown to pale olive-brown, some specimens with slightly darker olive-brown axial bands in the last half-whorl; apical and basal surfaces both glossy.
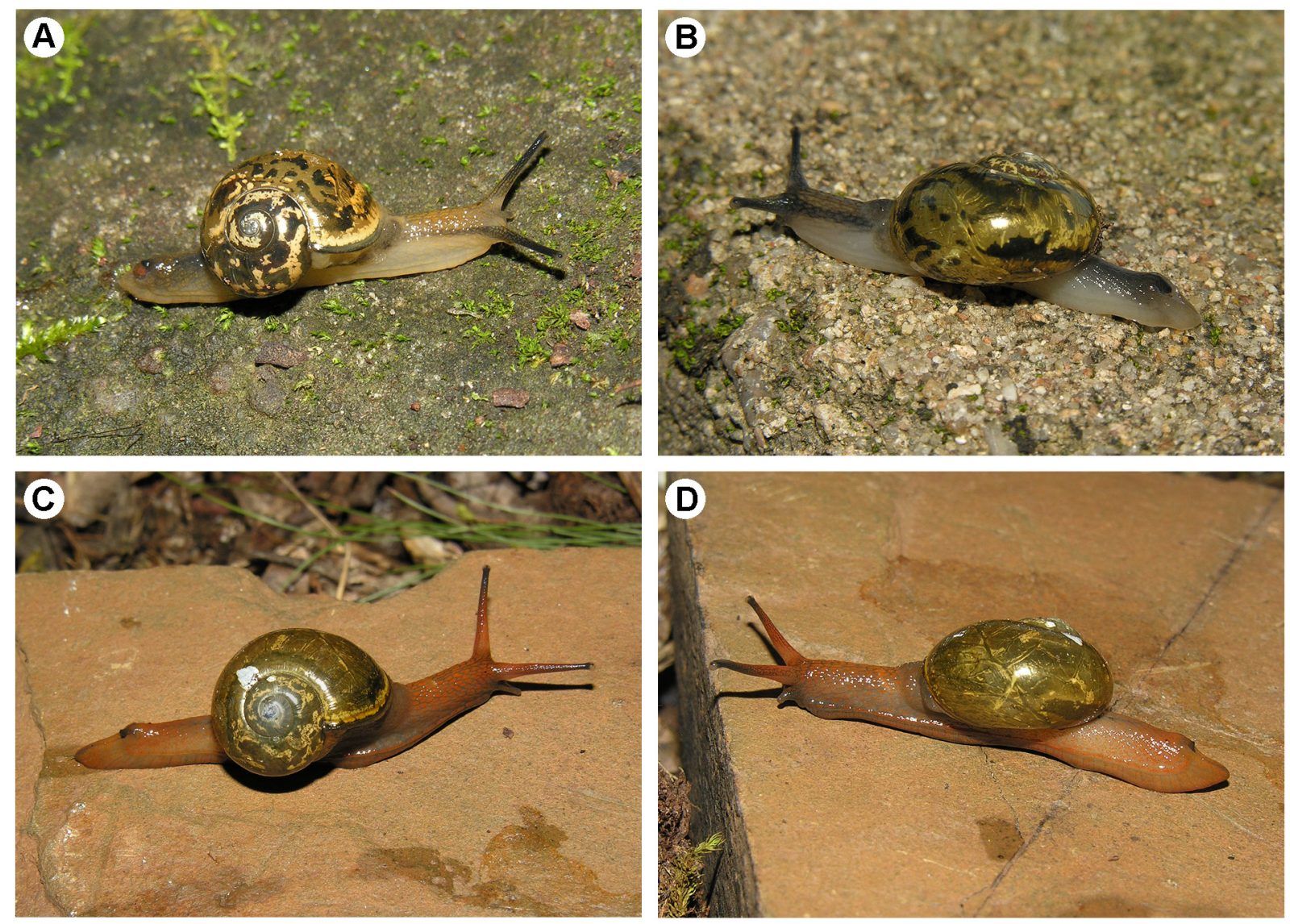

Fig. 10. Sheldonia monsmaripi sp. nov., living animals. A-B. Mariepskop Forest Reserve, mist-belt forest, shell diameter 11.6 mm (paratype, NMSA P0276/T4073). C-D. Mariepskop Forest Reserve, summit fynbos, shell diameter $16.3 \mathrm{~mm}$ (NMSA P0278). 
EXternal FeAtures (Fig. 10). Head and neck brownish to grey dorsally, not conspicuously spotted (cf. S. wolkbergensis sp. nov.), paler ventrally; tentacles darker grey with conspicuous dark retractor muscles passing down neck; posterior of foot and caudal appendage more uniformly darker grey dorsally, paler ventrally; some specimens with minute orange-brown pigment granules scattered throughout the skin, but particularly in the dorsal neck region; pulmonary region strongly pigmented. Body lobes of mantle edge grey; right and left shell lobes elongate-trigonal in preserved material. Mantle edge bordered with an irregular cream band, behind which the pulmonary lining is boldly and variably marked with irregular black and cream spots, blotches and bands, often more black than cream; black band overlying primary ureter, less conspicuous and often more irregular than in $S$. wolkbergensis sp. nov., and sometimes without a well-defined line of cream pigment to its right. Spire viscera dark grey-black with irregularly branching and anastomosing aggregations of cream pigmentation. A single living individual collected in the montane fynbos on top of Mariepskop was of a strikingly different coloration (Fig. 10C-D), the head-foot and optic tentacles being predominantly pale brick-red, and the pulmonary lining and viscera rather less densely pigmented.

RadULA (Fig. 11). Formula R+12+(1-2)+(50-60); rachidian tricuspid, laterals essentially bicuspid with a mesocone and strong basal ectocone, but also with a minute endocone on side of mesocone; laterals followed by $1-2$ intermediary teeth and then a long series of marginals; marginals curved and terminally bicuspid, tips of cusps bluntly rounded; outer marginals often with a third cusp on concave outer edge.

Distal genitalia (Fig. 12). Penis rather slender, cylindrical but narrowing slightly toward apex, enclosed in a thin sheath, mid-region may be bent or coiled inside sheath in contracted state; retractor muscle attached to penis apex. Lumen of basal portion of penis with longitudinal folds, two of which are somewhat
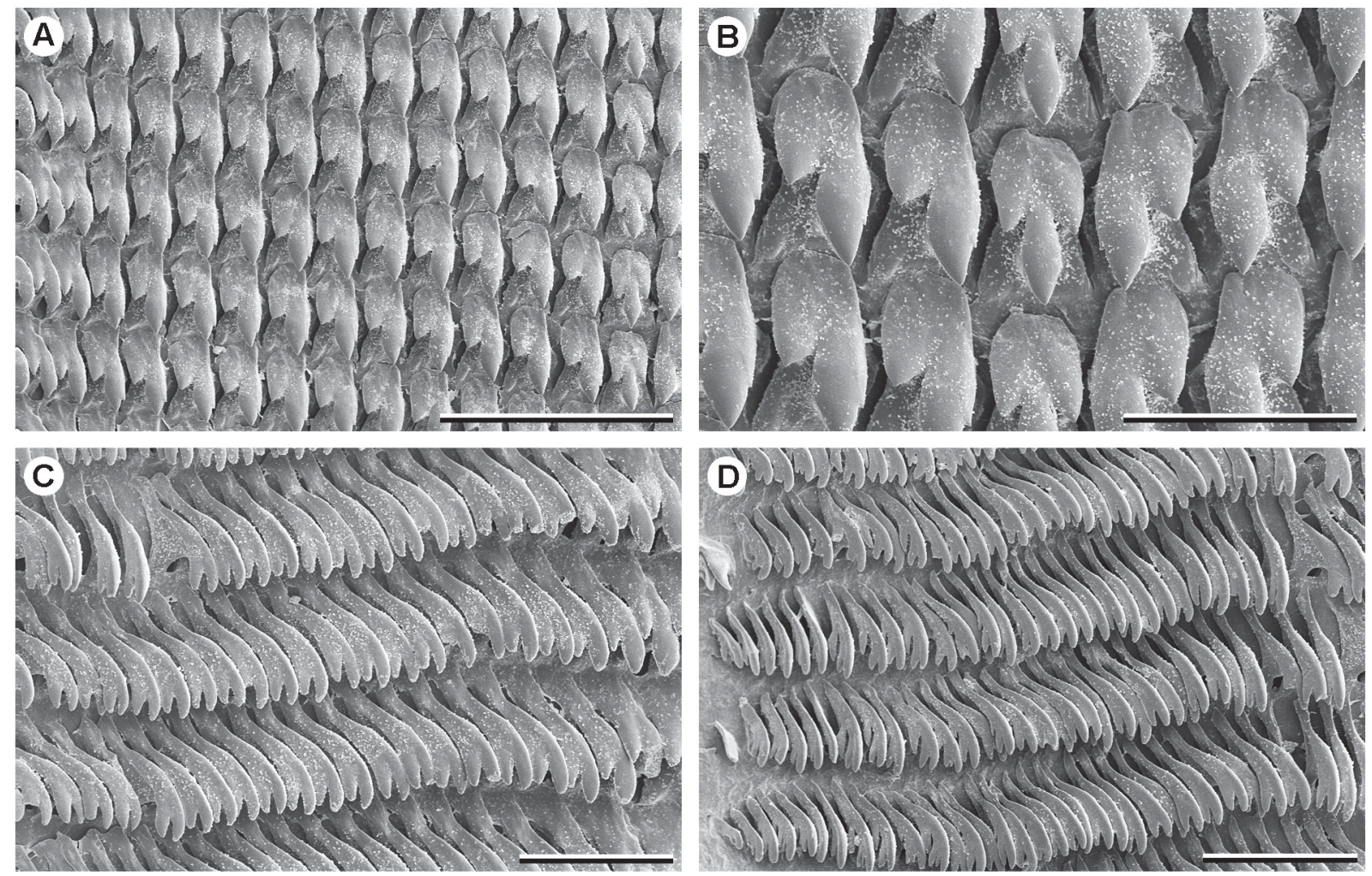

Fig. 11. Sheldonia monsmaripi sp. nov., radula, holotype (NMSA W4413/T3300). A. Rachidian and lateral teeth. B. Rachidian and innermost lateral teeth. C. Inner left marginal teeth. D. Outer left marginal teeth. Scale bars: $A=100 \mu \mathrm{m} ; \mathrm{B}-\mathrm{D}=50 \mu \mathrm{m}$. 
larger; folds more slender in apical portion; no evidence of a penial verge. Epiphallus short, relatively narrow near its junction with penis, but broader toward insertion of vas deferens; a well-developed, rather bulbous caecum arising one quarter to one third its length from penis. Flagellum divided into a short basal portion with transverse internal diverticulae (F1), and a longer, more slender, loosely coiled, apical portion with a simple tube-like internal core (F2). Junction of epiphallus and flagellum, at insertion of vas deferens, with opaque white contents; vas deferens simple and slender, tracking course of penis and vagina in life. Genital atrium simple, but with a large, elongate, thick-walled diverticulum arising adjacent to vagina and extending diagonally backward beneath penis and oesophagus to opposite side of body cavity; diverticulum connected to pedal floor by fine muscle fibres; lumen of diverticulum with two longitudinal ridges, between which are numerous fine, close-set transverse folds; ridges themselves also pleated with close-set, wavy, transverse folds. Vagina short; gametolytic sac elongate-reniform to obovate, thin-walled; its duct of similar length; base of free oviduct somewhat swollen, off-white; spermoviduct divided into distinct prostatic and oviductal portions. Spermatophore elbowed (Fig. 12D), with a large sinuous capsule and slender tail; early part of tail with several branched spines, the last of which is largest; tips of branches bifid; later part very thin, smooth and variously coiled.

\section{Distribution (Fig. 8)}

A narrow-range endemic, known only from the edge of the Drakensberg Escarpment in northern Mpumalanga, South Africa; at altitudes between 790 and $1920 \mathrm{~m}$ above sea level.

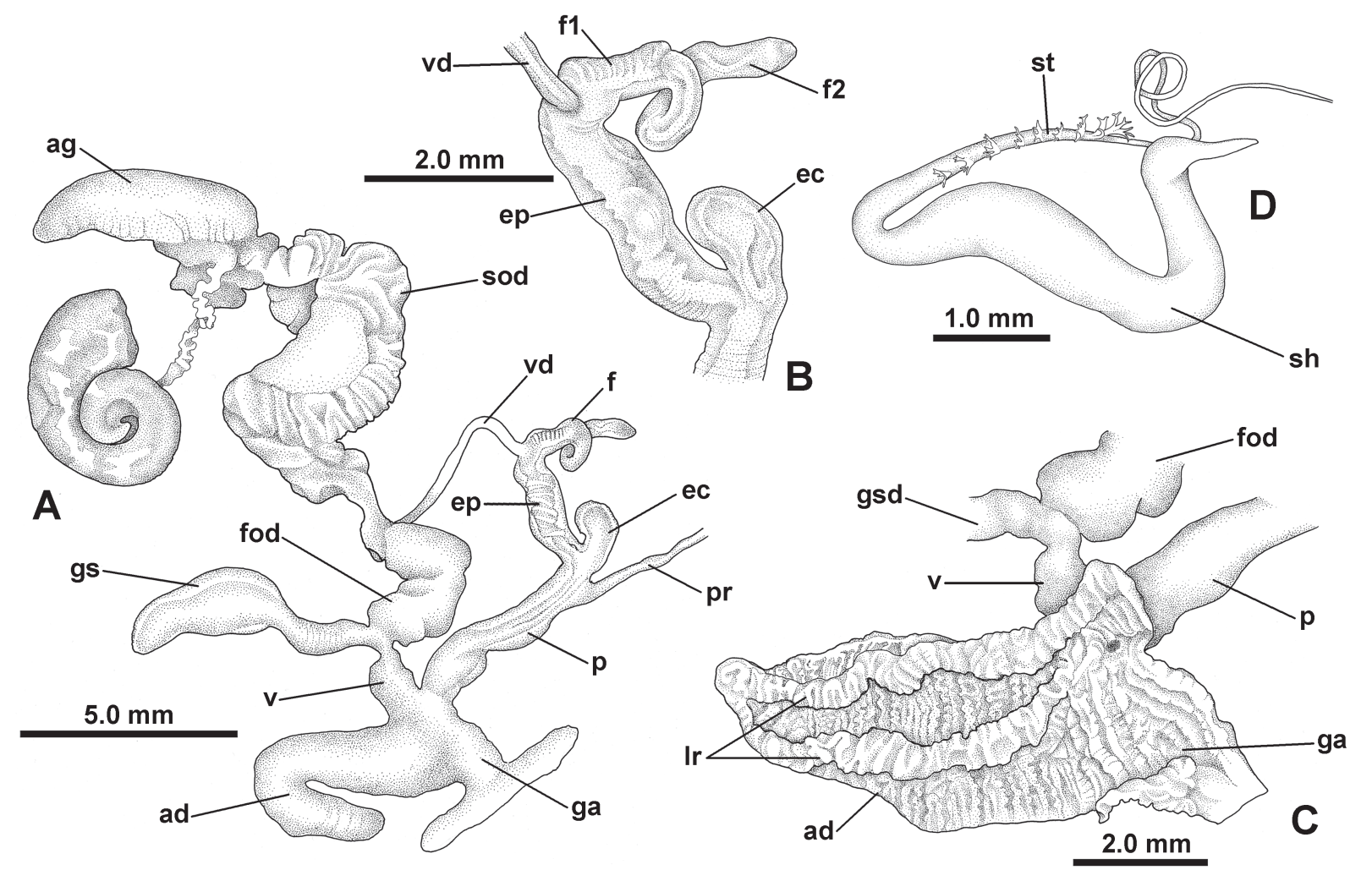

Fig. 12. Sheldonia monsmaripi sp. nov., genitalia, paratype (NMSA W3653/T3169). A. Entire genital system. B. Flagellum and distal epiphallus. C. Internal structure of genital atrium and atrial diverticulum. D. Spermatophore. 


\section{Habitat}

Northern mist-belt forest (Mucina \& Rutherford 2006); in leaf-litter, but more commonly among epiphytic plants growing on trees.

\section{Remarks}

Most of the available material was collected in forest habitat and such specimens are to be considered typical. Additional specimens of a larger size (diameter up to $18 \mathrm{~mm}$ ) (Fig. 9F) and with markedly different, orange-red, body pigmentation (Fig. 10C-D) have been collected in the Afromontane fynbos vegetation of the summit region of Mariepskop. However, although seemingly distinct on the basis of size and body colour, these specimens are otherwise indistinguishable from the forest form and have the same unusual, large atrial diverticulum. Pending evidence to the contrary, I consider these specimens to be an ecomorph of $S$. monsmaripi sp. nov. associated with the colder summit habitat of Mariepskop. Nevertheless, I have included in the type material only specimens from forest habitat.

Sheldonia monsmaripi sp. nov. is perhaps related to $S$. wolkbergensis sp. nov. from the neighbouring Wolkberg massif. The superficial features of the living animals are extremely similar and both possess an atrial diverticulum, an unusual feature in southern African Sheldonia species. There are, however, consistent differences in the form of the columella lip (non-rimate in S. monsmaripi sp. nov. and rimate in S. wolkbergensis sp. nov.); in the length of the gametolytic duct (very short in $S$. wolkbergensis sp. nov.); in the position of the epiphallic caecum relative to the penial retractor and the insertion of the vas deferens (close to penial retractor in S. monsmaripi sp. nov. and closer to vas deferens in S. wolkbergensis sp. nov.) and in the position of the atrial diverticulum (beneath oesophagus in $S$. monsmaripi sp. nov. and beneath buccal mass in $S$. wolkbergensis sp. nov.). In addition, $S$. wolkbergensis sp. nov. is smaller than S. monsmaripi sp. nov. and possesses a penial verge.

The non-rimate columella lip of $S$. monsmaripi sp. nov. is similar to that seen in some species of Sheldonia s.s., as well as 'Sheldonia' leucospira (Pfeiffer, 1847) and two additional undescribed species of Sheldonia s.l. from E Cape (Herbert unpubl. obs.), but none of these species possesses an atrial diverticulum. The presence of an atrial diverticulum has not previously been observed in shelled urocyclids from southern African. Van Mol (1970) reported such a structure in several Central and West African urocyclid genera, noting that its occurrence was sporadic and not fixed within members of the same genus. It may be present in one species, but absent in another, seemingly closely related species. The phylogenetic significance of its presence in both $S$. monsmaripi sp. nov. and $S$. wolkbergensis sp. nov. is thus difficult to evaluate, the more so since the internal structure of the organ differs in the two species. Given that they also differ with respect to several other features of distal reproductive tract morphology, the possession of an atrial diverticulum may be convergent.

Sheldonia wolkbergensis sp. nov. urn:1sid:zoobank.org:act:C7607188-AF52-4258-BF6A-4956282B6671

Figs $8,13-16$

\section{Etymology}

Named after the Wolkberg massif, to which the species is endemic.

\section{Material examined}

\section{Holotype}

SOUTH AFRICA: Limpopo, Wolkberg, Baccarat Forest, $23.88680^{\circ} \mathrm{S}, 30.01633^{\circ} \mathrm{E}, 1485 \mathrm{~m}$, northern mist-belt forest, in leaf-litter, D. Herbert, L. Davis \& M. Cole, stn 14-09, 26 Nov. 2014, diameter 7.7 $\mathrm{mm}$, height $5.2 \mathrm{~mm}$ (NMSA P0156/T4074, body in ethanol). 
Paratypes (listed north to south)

SOUTH AFRICA: Limpopo, Wolkberg, Grootbosch Forest, $23.76551^{\circ} \mathrm{S}, 30.00253^{\circ} \mathrm{E}, 1600 \mathrm{~m}$, Afromontane forest, living in leaf-litter, J. Swaye, stn L109, Dec. 2001 (NMSA W2263/T4108, three dry specimens); Wolkberg, Swartbos Forest, $23.88189^{\circ} \mathrm{S}, 29.99411^{\circ} \mathrm{E}, 1425 \mathrm{~m}$, Afromontane forest, in leaflitter, J. Swaye, stn L133, Dec. 2001 (NMSA W2084/T3166, two specimens, bodies in ethanol); same data as holotype (NMSA P0351/T4075, four specimens, bodies of two in ethanol); Wolkberg, Baccarat Forest, $23.88680^{\circ} \mathrm{S}, 30.01633^{\circ} \mathrm{E}, 1485 \mathrm{~m}$, Afromontane forest, in leaf-litter, J. Swaye, stn L103, Dec. 2001 (NMSA W2260/T3167, one dry specimen); Wolkberg, New Agatha Forest, 23.98298 S, $30.07696^{\circ} \mathrm{E}, 1620 \mathrm{~m}$, Afromontane forest, in leaf-litter, J. Swaye, stns L121, L125, Dec. 2001 (NMSA W2258/T3168, two specimens, body of one in ethanol).

\section{Type locality}

SOUTH AFRICA: Limpopo, Wolkberg, Baccarat Forest, $23.88680^{\circ} \mathrm{S}, 30.01633^{\circ} \mathrm{E}, 1485 \mathrm{~m}$.
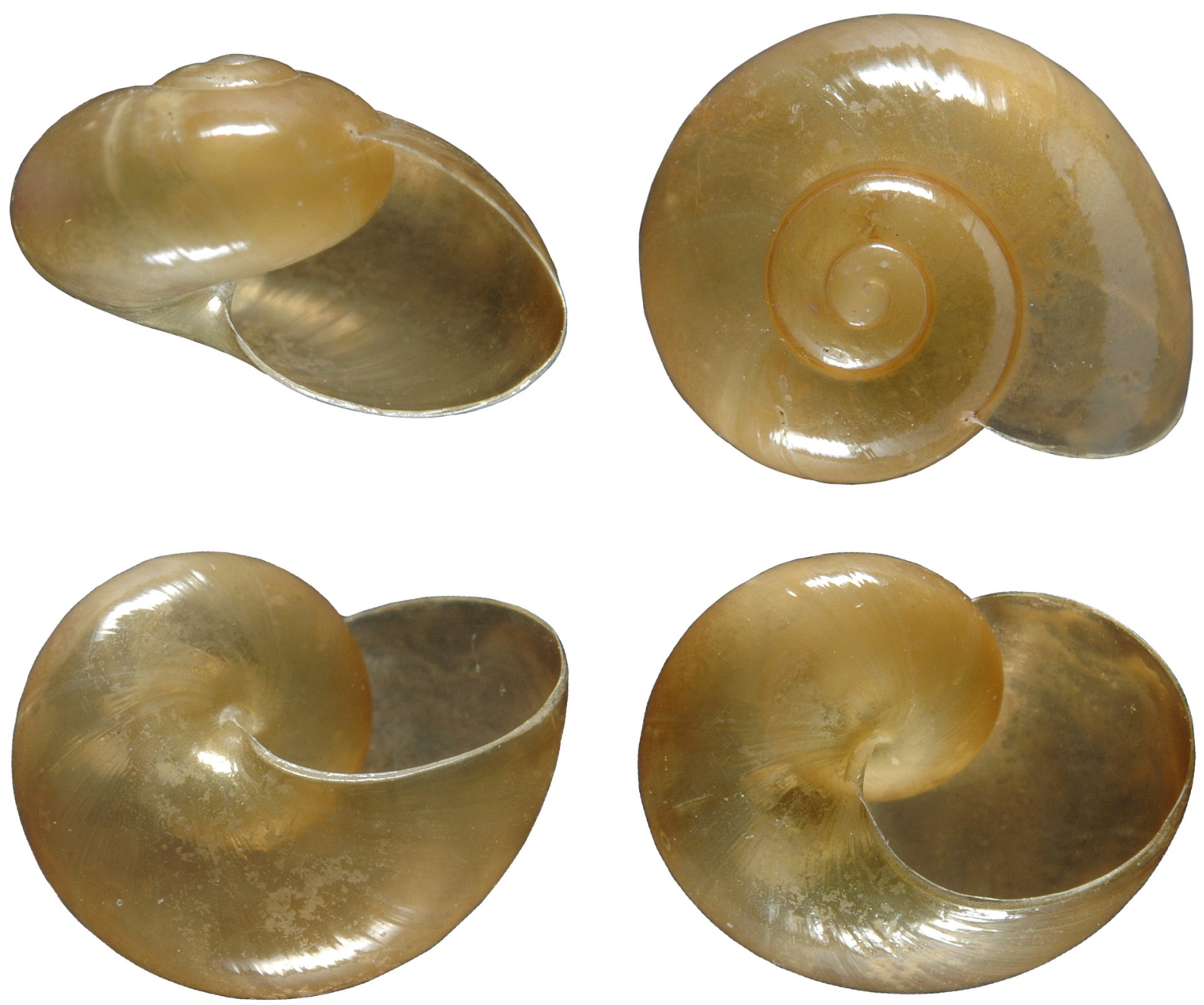

Fig. 13. Sheldonia wolkbergensis sp. nov., holotype, diameter $7.7 \mathrm{~mm}$, height $5.2 \mathrm{~mm}$ (NMSA P0156/ T4074). 


\section{Identification}

A small species characterised by its glossy, uniformly yellowish-brown shell, smooth protoconch and rimate columella lip. Distal genitalia with an atrial diverticulum, a large gametolytic sac with a very short duct, and a curved epiphallic caecum situated much closer to insertion of vas deferens than to penis retractor.

\section{Description}

SHELl (Fig. 13). Small, globose-lenticular to subglobose; largest specimen with diameter $9.4 \mathrm{~mm}$, height $6.5 \mathrm{~mm}$; H:D $0.65-0.75$; periphery close to or just below mid-whorl, evenly rounded; suture shallowly but distinctly indented, inserting well above periphery; very thin and delicate. Protoconch diameter $1.40-1.53 \mathrm{~mm}$; junction with teleoconch indistinct; smooth except for indistinct microscopic scratchlike spiral lines. Teleoconch of up to 2.5 whorls; whorls expanding moderately rapidly, with irregular and mostly weak growth-lines; spiral sculpture obsolete. Columella concave, its adapical region reflected over umbilical region and fused to adjacent part of base, forming a narrow flattened umbilical channel; aperture roundly lunate. Translucent, more or less uniformly yellowish-brown; apical and basal surfaces both glossy.

EXTERNAL FEATURES (Fig. 14). Head and neck dark grey dorsally, pale yellowish-buff ventrally, grey pigmentation associated with skin granules and thus appearing as dense spotting; tentacles brownish grey; posterior of foot more uniformly darker grey, particularly caudal appendage, but also with minute white pigment granules scattered between skin grooves; pulmonary region strongly pigmented. Mantle edge with well-developed right and left body lobes bearing some grey pigmentation; right and left shell lobes elongate-trigonal when extended over shell, pale and translucent, with scattered minute cream pigment granules. Pulmonary lining behind mantle edge bordered with cream and black blotches in a variable pattern; additional dark blotches and bands posterior to this with a very prominent and welldefined black band overlying primary ureter, to right of pale tissues of kidney; a further well-defined line of cream pigment to right of (i.e., dorsal to) black band. Spire viscera brown with occasional cream blotches and sparse, irregularly branching cream venation, but little or no black pigmentation. The caudal pit and appendage well developed.

RadULA (Fig. 15). Formula $\mathrm{R}+8+(1-2)+(40-50)$; rachidian tricuspid, laterals essentially bicuspid with a mesocone and strong basal ectocone, but also with a minute endocone on side of mesocone; laterals followed by 1-2 intermediary teeth and then a long series of marginals; marginals curved, bearing a large terminal cusp with a smaller subterminal cusp, followed by a series of finer serrations on concave outer margin, these proportionately stronger on smaller teeth toward edge of radula.
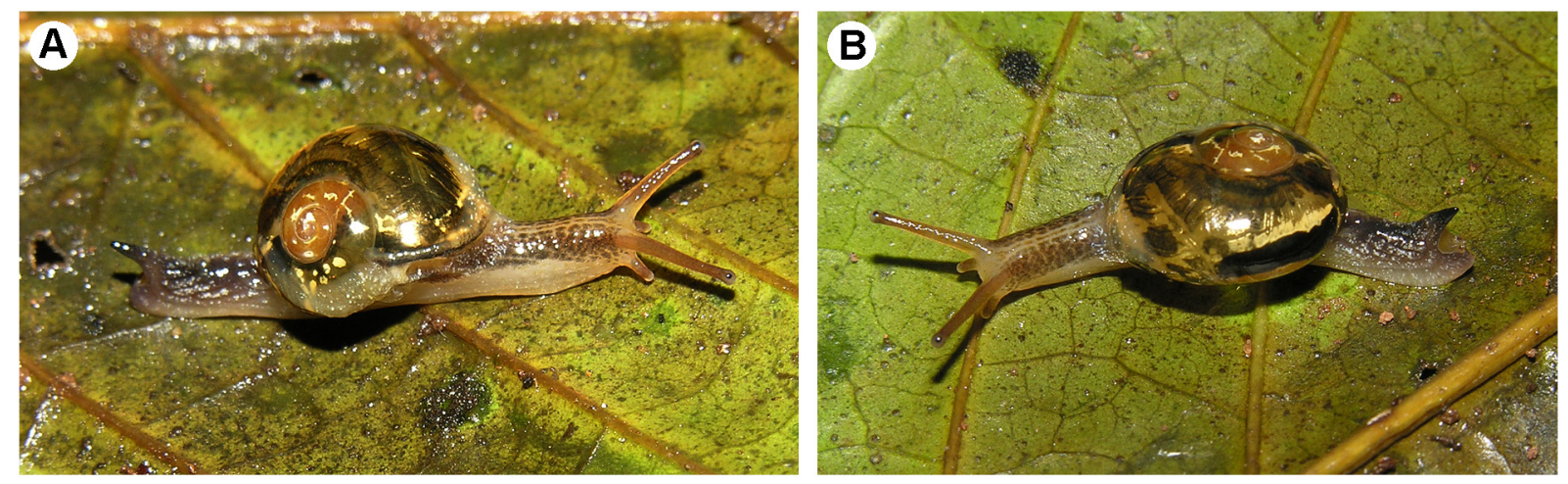

Fig. 14. Sheldonia wolkbergensis sp. nov., holotype, shell diameter 7.7 mm (NMSA P0156/T4074). 
Distal Genitalia (Fig. 16). Penis of moderate length, tapering somewhat toward apex, enclosed in a thin sheath, upper portion with a single coil; retractor muscle attached above this at penis apex; interior of penis with a verge at about one-third to half length from base (Fig. 16B); verge comprising a smooth trigonal flap encircling a central pore; penis lumen below verge (preputial region) with numerous, close-set papillae; lumen above verge with slender longitudinal folds. Epiphallus with a short, recurved caecum arising one-quarter of its length from insertion of vas deferens; proximal portion of epiphallus between vas deferens and caecum swollen, its lumen contents opaque white; distal portion more slender and resembling penis. Flagellum divided into F1 and F2; F1 short, swollen and with 6-7 transverse internal diverticulae; F2 somewhat longer, with 1-2 tight coils, with a simple tube-like internal core. Vas deferens simple and slender, tracking course of penis and vagina in life. Genital atrium large, with a conspicuous diverticulum arising on its antero-medial side; in life diverticulum lies beneath buccal mass; interior of diverticulum with anastomosing ridges and a large fleshy fold (stimulator), itself with superficial ridges (Fig. 16C). Vagina short, somewhat swollen; gametolytic sac large and thin-walled, globose but narrowing apically; gametolytic duct very short; base of free oviduct swollen, off-white; spermoviduct divided into distinct prostatic and oviductal portions. In one specimen the male distal genitalia were partially everted (Fig. 16D) with both the penis and the atrial diverticulum occupying a position in the genital atrium. The diverticulum was completely evaginated, with the fleshy stimulator at its tip. Spermatophore unknown.

\section{Distribution (Fig. 8)}

Anarrow-range endemic, known only from the Wolkberg region of the northern Drakensberg Escarpment in Limpopo, South Africa; at altitudes between 1425 and $1620 \mathrm{~m}$ above sea level.
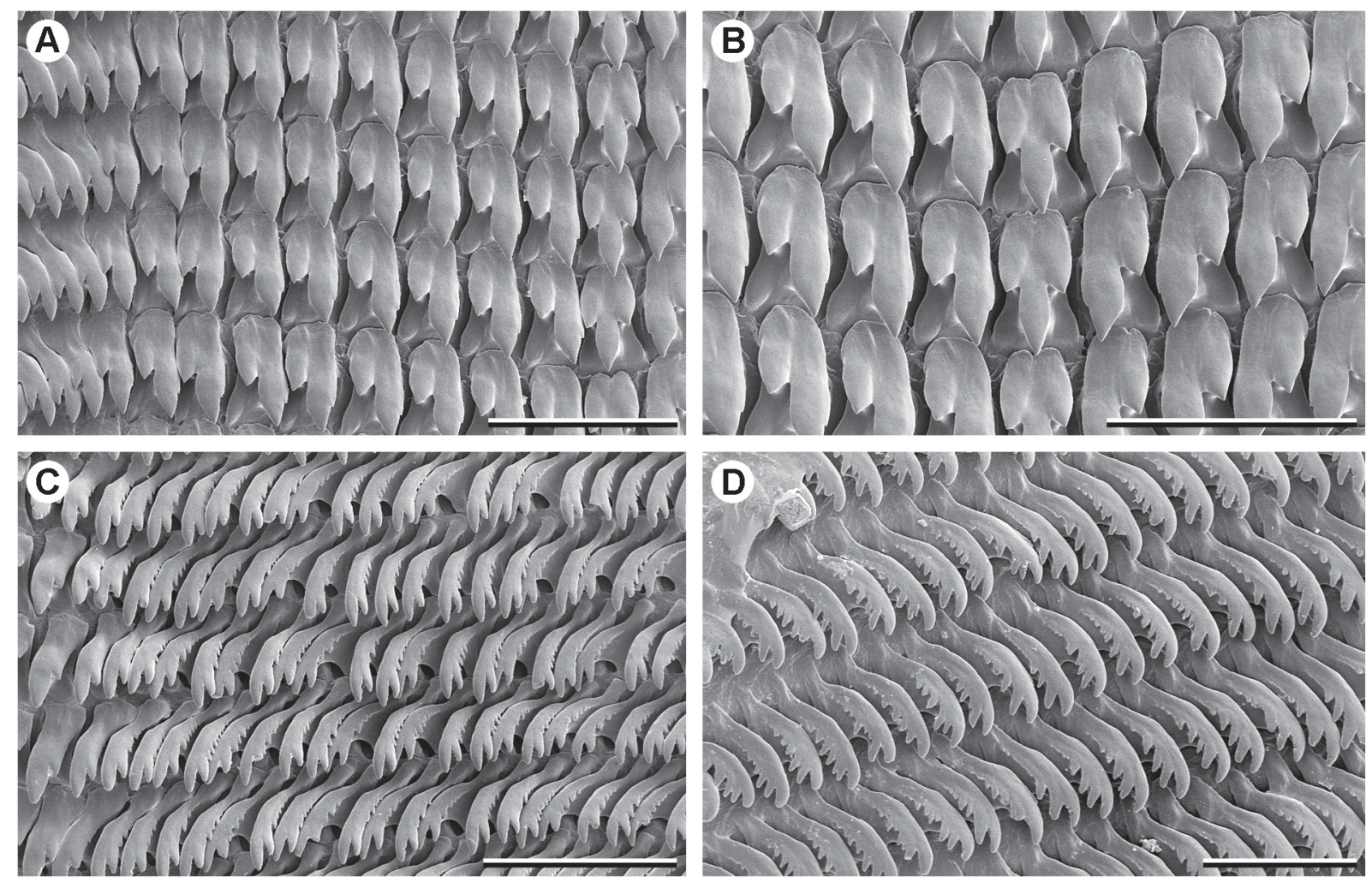

Fig. 15. Sheldonia wolkbergensis sp. nov., radula, holotype (NMSA P0156/T4074). A. Rachidian and lateral teeth. B. Rachidian and innermost lateral teeth. C. Inner marginal teeth. D. Outer marginal teeth. Scale bars: $\mathrm{A}-\mathrm{C}=50 \mu \mathrm{m} ; \mathrm{D}=25 \mu \mathrm{m}$. 


\section{Habitat}

Northern mist-belt forest (Mucina \& Rutherford 2006); all material collected to date was found in leaflitter.

\section{Remarks}

Sheldonia wolkbergensis sp. nov. is superficially similar to $S$. monsmaripi sp. nov. from forests on the neighbouring escarpment to the south, and both are unusual in possessing an atrial diverticulum. However, as discussed above, the similarities may be convergent. In terms of shell morphology, the two are easily distinguished on the basis of the columella lip morphology. In $S$. monsmaripi sp. nov., the columella is not reflected to form a rimate umbilical channel and an umbilicus is completely absent. There are additional differences in the distal genitalia that are detailed in the remarks relating to $S$. monsmaripi sp. nov. The pigmentation of the viscera is similar in both species, but in $S$. monsmaripi sp. nov. the spire viscera are darker and there is more cream pigmentation. S. wolkbergensis sp. nov. is evidently a small species, with individuals of $6.5 \mathrm{~mm}$ shell diameter possessing well-developed distal genitalia.

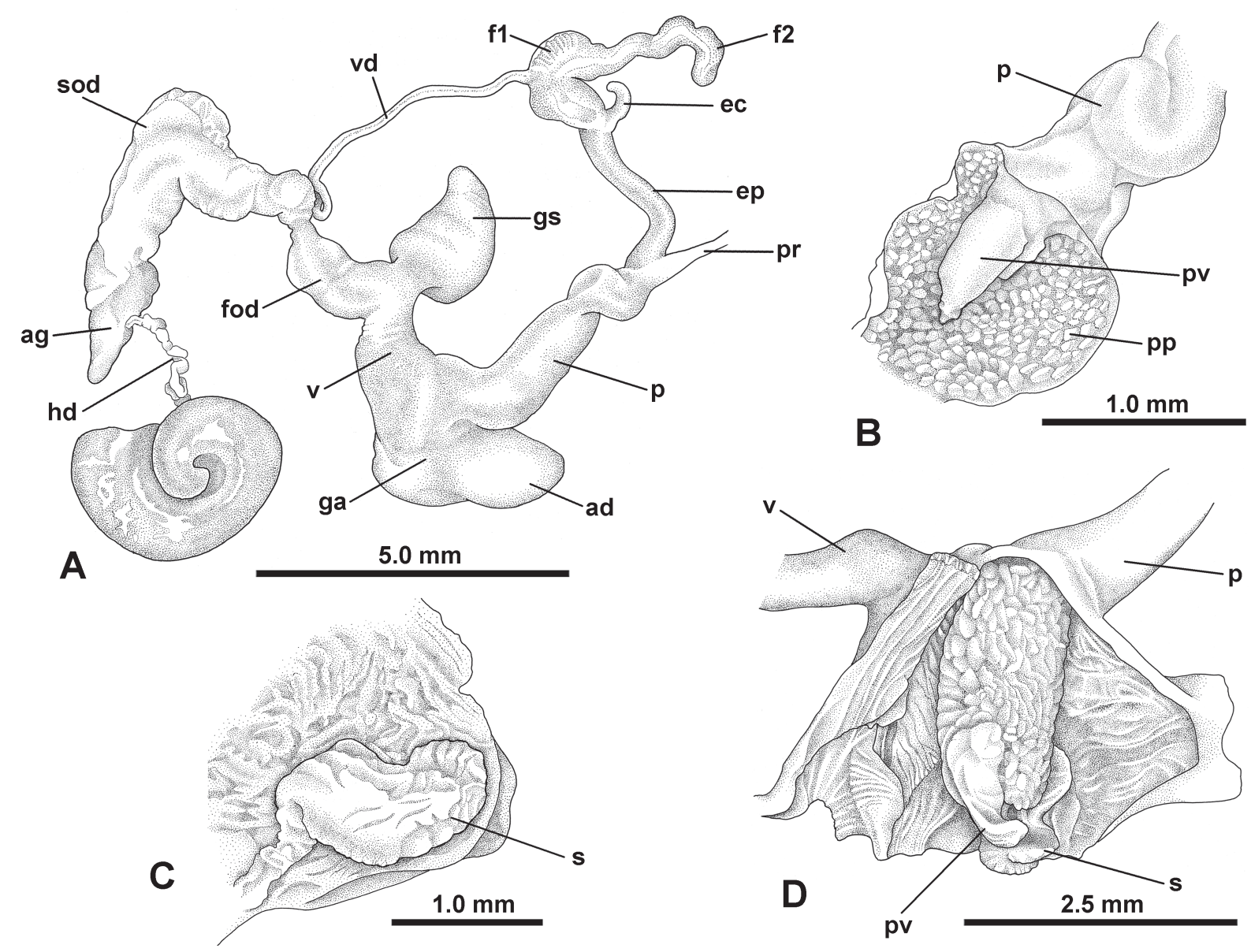

Fig. 16. Sheldonia wolkbergensis sp. nov., genitalia. A. Entire reproductive tract. B. Basal portion of penis opened to show penial verge. C. Atrial diverticulum dissected to show atrial stimulator. D. Partially everted distal genitalia with penis and stimulator protruding into genital atrium. A-C. Holotype (NMSA P0156/T4074). D. Paratype (NMSA W2258/T3168). 
The morphology of the distal genitalia of this species resembles that of species of Angustivestis Pilsbry, 1919 from central Africa (Van Mol 1970), but the duct of the gametolytic sac is much shorter in S. wolkbergensis sp. nov. and the whorls of the shell do not expand so rapidly.

\section{Discussion}

A number of narrowly endemic terrestrial molluscs have already been described from the Soutpansberg and/or Wolkberg centres of plant endemism. These are listed, together with the new species described herein, in Table 1. All belong to speciose genera prone to narrow-range neo-endemism. Others, such as Gulella deviae Herbert, 2006, G. herberti Bruggen, 2004 and G. wendalinae Bruggen, 1975, are nearendemic to these centres, but also range south into the Barberton Centre. All, with the possible exception of Sheldonia vandenbroeckii, are inhabitants of Afrotemperate forest. The latter, described simply from Lydenburg, remains a poorly known species that has not been collected since its initial discovery. The habitat in which it was found was not originally specified.

Further animal taxa endemic to these centres include seven species of harvestmen (Schönhofer 2008), the sac spider genus Vendaphaea (Haddad 2009) and the lizard Vhembelacerta rupicola (Edwards et al. 2013) from the Soutpansberg, as well as the butterflies Dingana clara and Alaena margaritacea (Woodhall 2005), and the reptiles Acontophiops lineatus, Afroedura multiporis, Lygodactylus methueni and Tetradactylus eastwoodae (Branch 1988) from the Wolkberg. The herpetofauna may also include a number of as yet undescribed taxa (Barnes \& Tarboton 1998; Tolley \& Burger 2007).

In addition to the endemic species mentioned above, the forests of the Soutpansberg and Wolkberg Centres contain further terrestrial gastropod taxa typical of Afrotemperate forests, with wider distributions. These emphasise that whereas these centres may represent islands for some taxa, for others a degree of connectivity has persisted (unless there is as yet undiscovered cryptic diversity). In many cases the distributions of these more widely ranging Afrotemperate species extend southward into KwaZulu-Natal, namely Cochlitoma dimidiata (Smith, 1878), Fauxulus ponsonbyanus (Morelet, 1889), Gulella contraria Connolly, 1932 and Gulella viae Burnup, 1925 (Bruggen 1972, 1985; Bruggen \& Meredith 1983; Herbert \& Kilburn 2004) and even to E Cape in the case of Macroptychia africana (Melvill \& Ponsonby, 1899) (Bruggen 1967). Rather fewer species range northwards across the arid, low-lying Limpopo Valley, a recognised biogeographic barrier for species inhabiting Afrotemperate forests (Stuckenberg 1962; Bruggen 1967, 1985), into the highlands of Zimbabwe, Mozambique and Malaŵi. Examples include Afroconulus diaphanus (Connolly, 1922) and Rhachistia chiradzuluensis (Smith, 1899) (Van Mol \& Bruggen 1971; Herbert \& Kilburn 2004). Macroptychia africana, belonging to the largely Eurasian family Clausiliidae, is an interesting species for although in the context of these forests it is a southern element reaching its northern distribution limit in the Soutpansberg, its congeners occur in the mountains of north-eastern Africa (Neubert 2002), where they exhibit high levels of local endemism associated with the larger mountain ranges. Bruggen (1967) considered M. africana a relict, palaeo-endemic species descendant and now widely disjunct from a north-eastern African stock.

Since all five species described herein are endemic to a single mountain block, their conservation is a matter of concern and each will need to be evaluated to establish its IUCN threat status. In the Soutpansberg, Ptilototheca soutpansbergensis gen. et sp. nov. is evidently not a rare species and it has been collected at localities spanning much of the mountain range ( $\sim 90 \mathrm{~km}$ linear distance). Similarly, in the northern Mpumalanga Drakensberg, Sheldonia monsmaripi sp. nov. ranges from Mariepskop south to the God's Window area ( $\sim 35 \mathrm{~km}$ linear distance), and presumably also occurs in forest patches along the intervening escarpment edge. These species are thus perhaps less threatened. In contrast, Sheldonia wolkbergensis sp. nov. is known from few individuals and is evidently scarce. Its known range spans a linear distance of only $25 \mathrm{~km}$. The two new species of Gulella are currently known only from the forests of Mariepskop and are effectively site endemics. The threat status of these and S. wolkbergensis 
Table 1. Land snail species endemic to the Soutpansberg and/or Wolkberg centres of plant endemism.

\begin{tabular}{lccc}
\hline Species & Soutpansberg & Wolkberg (Serala) & Wolkberg (Blyde) \\
\hline Gulella harriesi Burnup, 1926 & $\mathrm{X}$ & - & - \\
Gulella incurvidens Bruggen, 1972 & $\mathrm{X}$ & - & $\mathrm{X}$ \\
Gulella sibasana Connolly, 1922 & $\mathrm{X}$ & - & - \\
Ptilototheca soutpansbergensis sp. nov. & $\mathrm{X}$ & - & - \\
Trachycystis montissalinarum Bruggen, 2002 & $\mathrm{X}$ & $\mathrm{X}$ & $\mathrm{X}$ \\
Gulella inobstructa Bruggen, 1965 & - & $\mathrm{X}$ & $\mathrm{X}$ \\
Gulella johannae Bruggen, 2006 & - & $\mathrm{X}$ & - \\
Gulella verdcourti Bruggen, 1966 & - & $\mathrm{X}$ & - \\
Sheldonia wolkbergensis sp. nov. & - & $\mathrm{X}$ & - \\
Gulella davisae sp. nov. & - & - & $\mathrm{X}$ \\
Gulella hadroglossa sp. nov. & - & - & $\mathrm{X}$ \\
Sheldonia monsmaripi sp. nov. & - & - & $\mathrm{X}$ \\
Sheldonia vandenbroeckii (Craven, 1880) & - & - & $\mathrm{X}$ \\
\hline
\end{tabular}

sp. nov. will thus likely be higher. The conservation of all five will be dependent on the preservation of the Afrotemperate forest habitats remaining in these montane areas.

In all three regions habitat transformation has been considerable and commercial forestry plantations now cover extensive areas of what was originally a mosaic of Afrotemperate grassland and forest. The remaining native forest is now much fragmented and is under considerable threat from the spread of alien trees from surrounding plantations and disturbance related to these plantations (Barnes \& Tarboton 1998). A further threat to these forests and their inhabitants is presented by climate change, since this may alter the dynamics of the orographic phenomena to which they owe their existence.

\section{Acknowledgements}

I thank Mary Cole (East London Museum) and Linda Davis (KwaZulu-Natal Museum) for assistance in the field. Linda Davis also skilfully prepared the anatomical illustrations from my camera lucida drawings. In addition, I acknowledge the samples collected by Johanna Horn during her MSc studies at the University of KwaZulu-Natal. Permission to collect samples in 2014 was granted by the Limpopo Department of Economic Development, Environment and Tourism (permit No: 0094-MXT001-00001) and Mpumalanga Tourism and Parks (MPV.5109/5174). This research was supported by Incentive Funding from the South African National Research Foundation (Grant No 81078).

\section{References}

Aiken D.W. 1981. Differentiation of the radula of South African species of the genus Gulella into three types (Gastropoda Pulmonata: Streptaxidae). Journal of Conchology 30: 317-323.

Ancey C.F. 1887. Descriptions of new genera or subgenera of Helicidae. Conchologist's Exchange 1 (9-10): 53-54.

Barnes K.N \& Tarboton W.R. 1998. Important bird areas of the Northern Province. In: Barnes K.N. (ed.) The Important Bird Areas of Southern Africa: 47-63. Birdlife South Africa, Johannesburg.

Branch W. 1988. Field Guide to Snakes and Other Reptiles of Southern Africa. Struik Publishers, Cape Town. 
Bruggen A.C. van. 1967. Miscellaneous notes on southern African Gastropoda Euthyneura (Mollusca). Zoologische Verhandelingen 91: 1-34.

Bruggen A.C. van. 1972. New data on southern African Achatinidae (Mollusca, Gastropoda Pulmonata). Zoologische Mededelingen 47 (42): 513-529.

Bruggen A.C. van. 1985. Distribution and size of Gulella viae Bnp. and G. contraria Conn., two South African streptaxids (Gastropoda Pulmonata). Basteria 49: 47-54.

Bruggen A.C. van \& Meredith H.M. 1983. Fauxulus grayi n. sp., a biogeographically interesting addition to the land snail fauna of Malawii, south central Africa (Gastropoda Pulmonata: Orculidae). Proceedings of the Koninklijke Nederlandse Akademie van Wetenschappen Series C 86 (3): 309-323.

Connolly M. 1912. A revised reference list of South African non-marine Mollusca; with descriptions of new species in the South African Museum. Annals of the South African Museum 11: 59-306.

Connolly M. 1925. Notes on African non-marine Mollusca, with descriptions of many new species (continued). Annals and Magazine of Natural History Series 9, 15: 457-479, pl. 28.

Connolly M. 1939. A monographic survey of South African non-marine Mollusca. Annals of the South African Museum 33: 1-660.

Edwards S., Branch W.R., Vanhooydonck B., Herrel A., Measey G.J. \& Tolley K.A. 2013. Taxonomic adjustments in the systematics of the southern African lacertid lizards (Sauria: Lacertidae). Zootaxa 3669 (2): 101-114. http://dx.doi.org/10.11646/Zootaxa.3669.2.1

Godwin-Austen H.H. 1908. On Peltatus, gen. nov. Zonitidarum: Type P. hudsoniae (Benson). Annals and Magazine of Natural History Series 8, 1: 131-133. Available from http://biodiversitylibrary.org/ page/24295840 [accessed 10 Aug. 2016]

Godwin-Austen H.H. 1912. A review of the South-African land-Mollusca belonging to the family Zonitidae [Part I]. Annals and Magazine of Natural History Series 8, 9: 122-139. Available from http:// biodiversitylibrary.org/page/18638879 [accessed 10 Aug. 2016]

Govender V. 2007. Patterns of Distribution, Diversity and Endemism of Terrestrial Molluscs in South Africa. MSc Thesis, University of KwaZulu-Natal, South Africa.

Haddad C.R. 2009. Vendaphaea, a new dark sac spider genus apparently endemic to the Soutpansberg Mountains, South Africa (Araneae: Corinnidae). African Invertebrates 50: 269-278. http://dx.doi. org/10.5733/afin.050.0204

Herbert D.G. 2002. Gulella salpinx sp. n. a new, critically endangered, holoendemic species from the limestone deposits of the Marble Delta, KwaZulu-Natal, South Africa (Mollusca: Gastropoda: Streptaxidae). African Invertebrates 43: 125-138.

Herbert D. \& Kilburn D. 2004. Field Guide to the Land Snails and Slugs of Eastern South Africa. Natal Museum, Pietermaritzburg.

Horn J.L. 2004. The Invertebrates of Indigenous Forests in Limpopo Province South Africa: Diversity, Biogeography and Conservation. MSc Thesis, University of KwaZulu-Natal, South Africa.

Martens E. von. 1860. Die Heliceen, nach natürlicher Verwandtschaft systematisch geordnet von Joh. Christ. Albers. Zweite Ausgabe nach dem hinterlassenen Manuskript besorgt von Eduard von Martens. Wilhelm Engelmann, Leipzig. http://dx.doi.org/10.5962/bhl.title.11218

Mucina L. \& Rutherford M.C. (eds) 2006. The Vegetation of South Africa, Lesotho and Swaziland. Strelitzia 19, South African National Biodiversity Institute, Pretoria. 
Neubert E. 2002. The non-Alopiine Clausiliidae of Africa, with a note on Clausilia giraudi Bourguignat (Mollusca, Stylommatophora: Clausiliidae). Collectanea Malacologica, Festschrift für Gerhard Falkner: 253-275. ConchBooks, Hackenheim.

Pfeiffer L. 1856. Versuch einer Anordnung der Heliceen nach natürlichen Gruppen. Malakozoologische Blätter 2: 112-185. Available from http://biodiversitylibrary.org/page/15864853 [accessed 11 Aug. 2016]

Rowson B. 2010. Systematics and Diversity of the Streptaxidae (Gastropoda: Stylommatophora). PhD Thesis, University of Wales, Cardiff.

Rowson B. \& Herbert D.G. 2016. The type species and circumscription of the species-rich Afrotropical snail genus Gulella L. Pfeiffer, 1856, based on anatomical and mtDNA data (Mollusca: Eupulmonata: Streptaxidae). Archiv für Molluskenkunde 145 (1): 69-84. http://dx.doi.org/10.1127/arch.moll/1869$\underline{0963 / 145 / 069-084}$

Schileyko A.A. 2002. Treatise on Recent terrestrial pulmonate molluscs. Part 9. Helicarionidae, Gymnarionidae, Rhysotinidae, Ariophantidae. Ruthenica Supplement 2: 1167-1307.

Schönhofer A.L. 2008. On harvestmen from the Soutpansberg, South Africa, with description of a new species on Monomontia (Arachnida: Opiliones). African Invertebrates 49: 109-126. http://dx.doi. org/10.5733/afin.049.0206

Stuckenberg B.R. 1962. The distribution of the montane palaeogenic element in the South African invertebrate fauna. Annals of the Cape Provincial Museums 2: 190-205.

Tolley K. \& Burger M. 2007. Chameleons of Southern Africa. Struik Publishers, Cape Town.

Van Mol J.J. 1970. Révision des Urocyclidae (Mollusca, Gastropoda, Pulmonata) - anatomie systématique - zoogéographie. Première partie. Annales du Musée Royal de l'Afrique Centrale, Sciences zoologiques 180, Royal Museum for Central Africa, Tervuren.

Van Mol J.J. \& Bruggen A.C. van. 1971. Description d'un nouveau genre d'Euconulidae d'Afrique et discussion sur les affinités systématiques de cette famille (Mollusca, Gastropoda Pulmonata). Revue de Zoologie et de Botanique Africaine 84: 285-296.

Van Wyk A.E. \& Smith G.F. 2001. Regions of Floristic Endemism in Southern Africa. Umdaus Press, Pretoria.

Woodhall S. 2005. Field Guide to Butterflies of South Africa. Struik Publishers, Cape Town.

Manuscript received: 9 February 2016

Manuscript accepted: 28 April 2016

Published on: 12 October 2016

Topic editor: Rudy Jocqué

Section editor: Kurt Jordaens

Desk editor: Kristiaan Hoedemakers

Printed versions of all papers are also deposited in the libraries of the institutes that are members of the EJT consortium: Muséum national d'Histoire naturelle, Paris, France; Botanic Garden Meise, Belgium; Royal Museum for Central Africa, Tervuren, Belgium; Natural History Museum, London, United Kingdom; Royal Belgian Institute of Natural Sciences, Brussels, Belgium; Natural History Museum of Denmark, Copenhagen, Denmark; Naturalis Biodiversity Center, Leiden, the Netherlands. 